\title{
Synthesis, DFT Calculations, Antiproliferative, Bactericidal Activity and Molecular Docking of Novel Mixed-Ligand Salen/8-Hydroxyquinoline Metal Complexes
}

\author{
Badriah Saad Al-Farhan 1,*, Maram T. Basha ${ }^{2} \mathbb{D}$, Laila H. Abdel Rahman ${ }^{3, *}$, Ahmed M. M. El-Saghier ${ }^{3}$, \\ Doaa Abou El-Ezz ${ }^{4}$, Adel A. Marzouk ${ }^{5}$, Mohamed R. Shehata ${ }^{6}$ (D) and Ehab M. Abdalla ${ }^{7}$ (D)
}

check for

updates

Citation: Al-Farhan, B.S.; Basha, M.T.; Abdel Rahman, L.H.; El-Saghier, A.M.M.; Abou El-Ezz, D.; Marzouk, A.A.; Shehata, M.R.; Abdalla, E.M. Synthesis, DFT Calculations, Antiproliferative, Bactericidal Activity and Molecular Docking of Novel Mixed-Ligand Salen/ 8-Hydroxyquinoline Metal Complexes. Molecules 2021, 26, 4725 https://doi.org/10.3390/ molecules 26164725

Academic Editors: Helen Osborn Mohammad Najlah and Diego Muñoz-Torrero

Received: 17 June 2021

Accepted: 29 July 2021

Published: 4 August 2021

Publisher's Note: MDPI stays neutral with regard to jurisdictional claims in published maps and institutional affiliations.

Copyright: (c) 2021 by the authors. Licensee MDPI, Basel, Switzerland. This article is an open access article distributed under the terms and conditions of the Creative Commons Attribution (CC BY) license (https:// creativecommons.org/licenses/by/ $4.0 /)$.
1 Chemistry Department, Faculty of Girls for Science, King Khalid University, Abha 61421, Saudi Arabia

2 Chemistry Department, College of Science, University of Jeddah, Jeddah 21959, Saudi Arabia; marmarek-3@hotmail.com

3 Chemistry Department, Faculty of Science, Sohag University, Sohag 82534, Egypt; el.saghier@science.sohag.edu.eg

4 Pharmacology and Toxicology Department, Faculty of Pharmacy, October University for Modern Sciences and Arts (MSA University), Giza 12556, Egypt; Dabulez@msa.edu.eg

5 Department of Pharmaceutical Chemistry, Faculty of Pharmacy, Al-Azhar University, Assiut Branch, Assiut 71524, Egypt; adel_marzouk77@yahoo.com

6 Chemistry Department, Faculty of Science, Cairo University, Giza 12613, Egypt; mrshehata_05@hotmail.com

7 Chemistry Department, Faculty of Science, New Valley University, Alkharga 72511, Egypt; ehababdalla99@yahoo.com or ehababdalla99@sci.nvu.edu.eg

* Correspondence: shahd_bb@hotmail.com (B.S.A.-F.); lailakenawy@hotmail.com or laila.abdelrahman@science.sohag.edu.eg (L.H.A.R.); Tel.: +20-1098856153 (L.H.A.R.)

Abstract: Despite the common use of salens and hydroxyquinolines as therapeutic and bioactive agents, their metal complexes are still under development. Here, we report the synthesis of novel mixed-ligand metal complexes (MSQ) comprising salen (S), derived from (2,2'-\{1,2-ethanediylbis [nitrilo(E) methylylidene]\}diphenol, and 8-hydroxyquinoline (Q) with $\mathrm{Co}(\mathrm{II}), \mathrm{Ni}(\mathrm{II}), \mathrm{Cd}(\mathrm{II}), \mathrm{Al}(\mathrm{III})$, and $\mathrm{La}(\mathrm{III})$. The structures and properties of these MSQ metal complexes were investigated using molar conductivity, melting point, FTIR, ${ }^{1} \mathrm{H}$ NMR, ${ }^{13} \mathrm{C}$ NMR, UV-VIS, mass spectra, and thermal analysis. Quantum calculation, analytical, and experimental measurements seem to suggest the proposed structure of the compounds and its uncommon monobasic tridentate binding mode of salen via phenolic oxygen, azomethine group, and the $\mathrm{NH}$ group. The general molecular formula of MSQ metal complexes is $\left[\mathrm{M}(\mathrm{S})(\mathrm{Q})\left(\mathrm{H}_{2} \mathrm{O}\right)\right]$ for $\mathrm{M}(\mathrm{II})=\mathrm{Co}, \mathrm{Ni}$, and $\mathrm{Cd}$ or $[\mathrm{M}(\mathrm{S})(\mathrm{Q})(\mathrm{Cl})]$ and $\left[\mathrm{M}(\mathrm{S})(\mathrm{Q})\left(\mathrm{H}_{2} \mathrm{O}\right)\right] \mathrm{Cl}$ for $\mathrm{M}(\mathrm{III})=\mathrm{La}$ and $\mathrm{Al}$, respectively. Importantly, all prepared metal complexes were evaluated for their antimicrobial and anticancer activities. The metal complexes exhibited high cytotoxic potency against human breast cancer (MDA-MB231) and liver cancer (Hep-G2) cell lines. Among all MSQ metal complexes, CoSQ and LaSQ produced $\mathrm{IC}_{50}$ values $(1.49$ and $1.95 \mu \mathrm{M}$, respectively) that were comparable to that of cisplatin $(1.55 \mu \mathrm{M})$ against Hep-G2 cells, whereas CdSQ and LaSQ had best potency against MDA-MB231 with $\mathrm{IC}_{50}$ values of 1.95 and $1.43 \mu \mathrm{M}$, respectively. Furthermore, the metal complexes exhibited significant antimicrobial activities against a wide spectrum of both Grampositive and -negative bacterial and fungal strains. The antibacterial and antifungal efficacies for the MSQ metal complexes, the free $S$ and $Q$ ligands, and the standard drugs gentamycin and ketoconazole decreased in the order AlSQ $>$ LaSQ $>$ CdSQ $>$ gentamycin $>$ NiSQ $>$ CoSQ $>$ Q $>$ S for antibacterial activity, and for antifungal activity followed the trend of LaSQ $>$ AlSQ $>$ CdSQ $>$ ketoconazole $>$ NiSQ $>$ CoSQ $>$ Q $>$ S. Molecular docking studies were performed to investigate the binding of the synthesized compounds with breast cancer oxidoreductase (PDB ID: 3HB5). According to the data obtained, the most probable coordination geometry is octahedral for all the metal complexes. The molecular and electronic structures of the metal complexes were optimized theoretically, and their quantum chemical parameters were calculated. PXRD results for the $\mathrm{Cd}(\mathrm{II})$ and $\mathrm{La}(\mathrm{III})$ metal complexes indicated that they were crystalline in nature. 
Keywords: anticancer; antimicrobial; mixed-ligand; salen; 8-hydroxyquinoline; quantum calculation

\section{Introduction}

Metal complexes constitute an important class of materials and are encountered daily. Metal complexes show remarkable stability compared to their ligands and metals alone, owing to the chelate effect [1]. An informed selection of metal conductors and ligand bridges allows for the application of such metal complexes in adsorption, ion exchange, and separation [2]; biomimetic and heterogeneous catalysis [3,4]; biomedical applications; sensor technologies [5]; luminescence [6-8]; proton conductivity [9]; and drug delivery [7,8]. The structural study of mixed-ligand metal complexes can provide information on how biological systems attain their stability and specificity [10]. Accordingly, we have selected two metal complexing agents, namely, salen and 8-hydroxyquinoline ligands, to prepare new mixed-ligand metal complexes.

Salen (S) is an excellent ligand that contains $\mathrm{N}_{2} \mathrm{O}_{2}$ donor sites through which it readily binds to metal ions forming metal complexes with octahedral, tetrahedral, or square planar geometries [11-13]. The large numbers of studies on salen highlight its importance [14-24]. 8-Hydroxyquinoline (typically abbreviated to $Q$ in its metal complexes) and its derivatives are found in plants and have also been prepared synthetically. Owing to their chelating ability towards many metal cations, hydroxyquinoline derivatives have found many applications. For instance, they are used as preservatives in the textile industry and as fungicides in the agricultural, paper, and wood industries [25]. Furthermore, they are widely used in metal-metal complexation research and as antibacterial, insecticidal, neuroprotective, and anti-HIV agents in medicine [26,27].

Motivated by the uncommon tridentate salen binding in its mixed-ligand metal complexes with imidazole MSI, together with our growing interest in the properties/applications of Schiff base metal complexes, we report in this contribution the synthesis, photophysical properties, and DFT calculations of new mixed-ligand of salen/8-hydroxyquinoline metal complexes (MSQ; $\mathrm{M}=\mathrm{Co}(\mathrm{II}), \mathrm{Ni}(\mathrm{II})$, and $\mathrm{Cd}(\mathrm{II})$, or $\mathrm{Al}(\mathrm{III})$ and $\mathrm{La}(\mathrm{III})$ ions). Analytical and theoretical (DFT) structural characterizations revealed a mono basic tridentate coordination mode of the salen ligand and bidentate for 8-hydroxyquinoline to afford octahedral geometries of the general formula $[\mathrm{M}(\mathrm{S})(\mathrm{Q})(\mathrm{X})], \mathrm{X}=\mathrm{H}_{2} \mathrm{O}$ or $\mathrm{Cl}$. Importantly, the antimicrobial activities of the prepared MSQ metal complexes were evaluated and compared with those of their salen/imidazole MSI analogues. Additionally, the cytotoxicity of the MSQ metal complexes against the liver carcinoma (Hep-G2) and the breast cancer (MDA-MB231) carcinoma cell lines were investigated.

\section{Materials and Methods}

\subsection{Reagents}

Ethylene diamine, salicylaldehyde, 8-hydroxyquinoline, sodium hydroxide, lanthanum(III) chloride $\left(\mathrm{LaCl}_{3} 7 \mathrm{H}_{2} \mathrm{O}\right)$, aluminum(III) chloride $\left(\mathrm{AlCl}_{3} 6 \mathrm{H}_{2} \mathrm{O}\right)$, cadmium(II) chloride $\left(\mathrm{CdCl}_{2} \mathrm{H}_{2} \mathrm{O}\right)$, nickel(II) chloride $\left(\mathrm{NiCl}_{2} 6 \mathrm{H}_{2} \mathrm{O}\right)$, and cobalt(II) chloride $\left(\mathrm{CoCl}_{2} 6 \mathrm{H}_{2} \mathrm{O}\right)$ were purchased from (Sigma Aldrich Chemie $\mathrm{GmbH}$, München, Germany). Organic solvents, including absolute ethanol and dimethyl sulfoxide (DMSO), were provided at reagent grade, and used without purification.

\subsection{Characterization}

The melting and decomposition points of salen and its mixed 8-hydroxyquinoline metal complexes were measured on a Gallen Kamp apparatus (Nikon Corporation, Tokyo, Japan). FTIR spectra of the metal complexes in the region 400 to $4000 \mathrm{~cm}^{-1}$ were recorded from $\mathrm{KBr}$ pellets using a Shimadzu FTIR spectrophotometer model 8101 (Shimadzu Corporation, Kyoto, Japan). A JENWAY model 4320 conductivity meter (Pontypool, UK) was used to measure the molar conductance of the metal complexes. UV-VIS spectra were 
recorded in DMSO using a Jasco model V-530 spectrophotometer (JASCO, Easton, MD, USA). FT-NMR spectrometer (Bruker ARX 400.1) (Billerica, MA, USA) at $400 \mathrm{MHz}\left({ }^{1} \mathrm{H}\right)$ and $100.6 \mathrm{MHz}\left({ }^{13} \mathrm{C}\right)$ was used to record ${ }^{1} \mathrm{H}$ NMR and ${ }^{13} \mathrm{C}$ NMR spectra in DMSO- $d_{6}$ utilizing TMS as an internal standard (Sohag University, Faculty of Science, Chemistry Department Central Lab.). Mass spectra were obtained with an (MS-5988 GS-MS, USA) Hewlett-Packard instrument at the Microanalytical Center, National Center for Research, Dokki, Egypt, using electrospray ionization at $70 \mathrm{eV}$. Elemental analyses of salen and its metal complexes were performed in Cairo University with a Perkin-Elmer 240c elemental analyzer. Magnetic measurements were performed using a Guy's balance. Additionally, Shimadzu corporation $60 \mathrm{H}$ analyzer was utilized to obtain the thermograms of the metal complexes in air with a heating rate of $10^{\circ} \mathrm{C} / \mathrm{min}$ from ambient temperature to $800^{\circ} \mathrm{C}$. A HANNA $211 \mathrm{pH}$ meter (Merck KGaA, Darmstadt, Germany) was used to measure the $\mathrm{pH}$ values using Britton universal buffers. Anticancer activity was evaluated using the ELISA technique, and a microplate reader (Meter tech. $\Sigma 960$, Winooski, VT, USA) was used to measure the absorbance results at $564 \mathrm{~nm}$.

\subsection{Synthesis of Salen}

In a round flask, $0.601 \mathrm{~g}(0.01 \mathrm{~mol})$ ethylenediamine and $2.44 \mathrm{~g}(0.02 \mathrm{~mol})$ salicylaldehyde were mixed in $50 \mathrm{~mL}$ absolute ethanol and refluxed for $60 \mathrm{~min}$. The reaction mixture was concentrated to half of its volume, whereupon the yellow precipitate formed was isolated by filtration, washed with ethanol, and dried at laboratory temperature [28]. Yield 96\%; M. p. $127^{\circ} \mathrm{C}$; FTIR $\left(\mathrm{KBr}, \mathrm{cm}^{-1}\right)$ : $3292(\mathrm{OH}), 3049-3007(\mathrm{CH})_{\text {arom }}, 2899-2867(\mathrm{CH})_{\text {aliph }}$ $1608(\mathrm{C}=\mathrm{N}), 1217(\mathrm{C}-\mathrm{C}) ;{ }^{1} \mathrm{H}$ NMR (DMSO- $\left.d_{6} / \mathrm{D}_{2} \mathrm{O}, 400 \mathrm{MHz}\right): 3.87\left(\mathrm{t}, 4 \mathrm{H}, \mathrm{N}-\mathrm{CH}_{2}-\mathrm{CH}_{2}-\mathrm{N}\right)$, 6.69-7.37 (m, 8H, Ar-H), 8.54 (s, 2H, $2 \mathrm{~N}=\mathrm{CH}), 13.3$ (br s, 2H, $2 \mathrm{ArOH}) ;{ }^{13} \mathrm{C}$ NMR $(100 \mathrm{MHz}$, DMSO- $\left.d_{6}\right): 58.68,116.99,119.00,132.22,132.94,161.19,167.28$.

\subsection{Synthesis of Mixed Metal Complexes (MSQ)}

Into a boiling flask, we added $1 \mathrm{mmol}$ of the metal salt $(0.238 \mathrm{~g}$ of $\mathrm{Co}(\mathrm{II}), 0.236 \mathrm{~g}$ of $\mathrm{Ni}(\mathrm{II}), 0.201 \mathrm{~g}$ of $\mathrm{Cd}(\mathrm{II}), 0.241 \mathrm{~g}$ of $\mathrm{Al}(\mathrm{III})$, or $0.372 \mathrm{~g}$ of $\mathrm{La}(\mathrm{III}))$ and $0.268 \mathrm{~g}(1 \mathrm{mmol})$ of salen in $10 \mathrm{~mL}$ of an aqueous ethanolic mixture. The reaction mixture was then refluxed at $79^{\circ} \mathrm{C}$ with constant stirring, and after $1 \mathrm{~h}, 0.145 \mathrm{~g}(1 \mathrm{mmol})$ of 8-hydroxyquinoline in $10 \mathrm{~mL}$ ethanol was added dropwise. The reaction was then refluxed for another $1 \mathrm{~h}$. The resulting reaction mixture was left to cool and evaporate overnight. The colored solid products (dark brown for CoSQ, brownish-red for NiSQ, dark-yellow for CdSQ, light-yellow for AlSQ, and dark-yellow for LaSQ) were filtered from the reaction mixture, thoroughly washed with ethanol to remove any traces of unreacted starting materials, and dried under vacuum. The purity of the metal complexes was checked by TLC [29,30] (Scheme 1). The yields, melting points, conductance values, magnetic moments, and elemental analysis results for the mixed-ligand metal complexes are shown in (Table 1).

\subsection{Computational Study}

The lowest energy geometries of the ligands and their metal complexes were derived using DFT at the DFT / B3LYP/6-311++g $(\mathrm{d}, \mathrm{p})$ level of theory for $\mathrm{C}, \mathrm{H}, \mathrm{N}$, and $\mathrm{O}$ atoms and LANL2DZ for metals, utilizing the Gaussian09 program [31]. IR Frequency calculations were performed on the optimized geometries, showing that all the converged states correspond to true minima (no imaginary frequencies). 


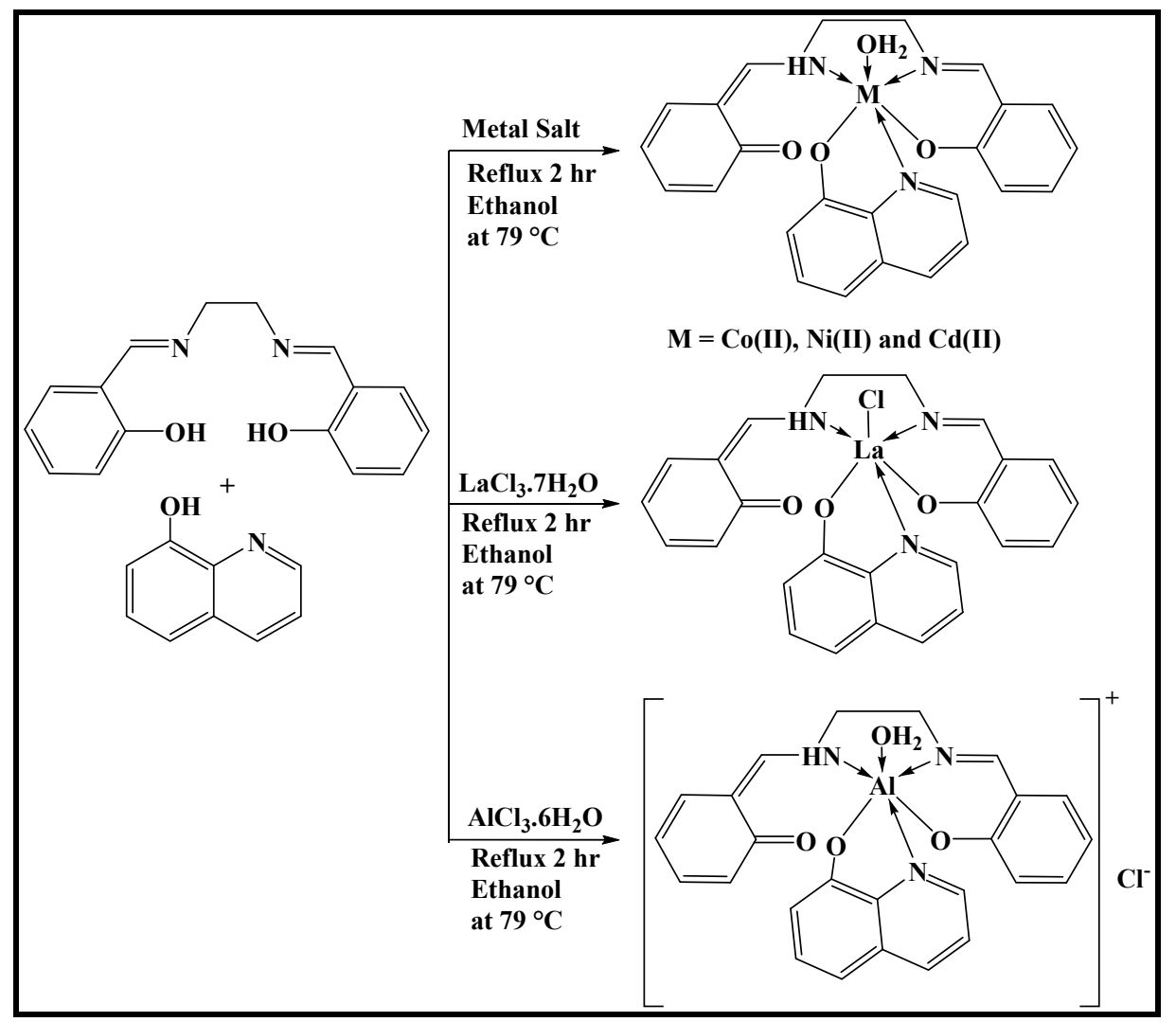

Scheme 1. Synthesis pathway for $\mathrm{Co}(\mathrm{II}), \mathrm{Ni}(\mathrm{II}), \mathrm{Cd}(\mathrm{II}), \mathrm{Al}(\mathrm{III})$, and $\mathrm{La}(\mathrm{III})$ of mixed salen ligand metal complexes with 8-hydroxyquinolone.

Table 1. Analytical data for salen and salen/8-hydroxy quinoline mixed-ligand metal complexes of $\mathrm{Co}(\mathrm{II}), \mathrm{Ni}(\mathrm{II}), \mathrm{Cd}(\mathrm{II})$, $\mathrm{Al}(\mathrm{III})$, and $\mathrm{La}(\mathrm{III})$.

\begin{tabular}{|c|c|c|c|c|c|c|c|c|c|}
\hline \multirow{2}{*}{$\begin{array}{c}\text { Compounds Molecular } \\
\text { Formula }\end{array}$} & \multirow{2}{*}{$\begin{array}{l}\text { Molecular } \\
\text { Weight }\end{array}$} & \multirow{2}{*}{ Color Yield \% } & \multirow{2}{*}{$\begin{array}{c}\text { Conductivity } \\
\mu \mathrm{s}\end{array}$} & \multirow{2}{*}{ M. P. ${ }^{\circ} \mathrm{C}$} & \multirow{2}{*}{$\mu_{\text {eff }} \mathbf{B M}$} & \multicolumn{4}{|c|}{ Found (cal.) \% } \\
\hline & & & & & & $\mathrm{C}$ & $\mathbf{H}$ & $\mathbf{N}$ & $\mathbf{M}$ \\
\hline $\begin{array}{c}\text { Salen } \\
\mathrm{C}_{16} \mathrm{H}_{16} \mathrm{~N}_{2} \mathrm{O}_{2} \\
\end{array}$ & 268.31 & $\begin{array}{l}\text { Yellow } \\
95\end{array}$ & 0.83 & 127 & 0.576 & $\begin{array}{c}71.32 \\
(71.62) \\
\end{array}$ & $\begin{array}{l}5.95 \\
(6.01) \\
\end{array}$ & $\begin{array}{l}10.28 \\
(10.44)\end{array}$ & - \\
\hline $\begin{array}{l}\text { 8-Hydroxyquinoline } \\
\qquad \mathrm{C}_{9} \mathrm{H}_{7} \mathrm{NO}\end{array}$ & 145.16 & $\begin{array}{c}\text { White } \\
\text { - }\end{array}$ & - & 76 & - & $\begin{array}{c}74.25 \\
(74.47)\end{array}$ & $\begin{array}{c}4.67 \\
(4.86)\end{array}$ & $\begin{array}{c}9.49 \\
(9.65)\end{array}$ & - \\
\hline $\begin{array}{c}\mathrm{Co}(\mathrm{S})(\mathrm{Q}) \mathrm{H}_{2} \mathrm{O} \\
\mathrm{C}_{25} \mathrm{H}_{23} \mathrm{CoN}_{3} \mathrm{O}_{4}\end{array}$ & 488.4 & $\begin{array}{c}\text { Dark brown } \\
89 \\
\end{array}$ & 42.8 & 260 & 2.3 & $\begin{array}{c}61.34 \\
(61.48) \\
\end{array}$ & $\begin{array}{c}4.51 \\
(4.75)\end{array}$ & $\begin{array}{c}8.52 \\
(8.60) \\
\end{array}$ & $\begin{array}{l}11.99 \\
(12.07)\end{array}$ \\
\hline $\begin{array}{c}\mathrm{Ni}(\mathrm{S})(\mathrm{Q}) \mathrm{H}_{2} \mathrm{O} \\
{\left[\mathrm{C}_{25} \mathrm{H}_{23} \mathrm{~N}_{3} \mathrm{NiO}_{4}\right] 0.5 \mathrm{H}_{2} \mathrm{O}}\end{array}$ & 497.16 & $\begin{array}{c}\text { Brownish red } \\
75 \\
\end{array}$ & 53.3 & $>300$ & 1.4 & $\begin{array}{c}60.21 \\
(60.34) \\
\end{array}$ & $\begin{array}{c}4.59 \\
(4.82) \\
\end{array}$ & $\begin{array}{c}8.12 \\
(8.44) \\
\end{array}$ & $\begin{array}{l}11.69 \\
(11.80)\end{array}$ \\
\hline $\begin{array}{c}\mathrm{Cd}(\mathrm{S})(\mathrm{Q}) \mathrm{H}_{2} \mathrm{O} \\
\mathrm{C}_{25} \mathrm{H}_{23} \mathrm{CdN}_{3} \mathrm{O}_{4}\end{array}$ & 541.88 & $\begin{array}{c}\text { Dark yellow } \\
79 \\
\end{array}$ & 34.8 & 282 & Dia. & $\begin{array}{c}55.15 \\
(55.41) \\
\end{array}$ & $\begin{array}{c}4.08 \\
(4.28) \\
\end{array}$ & $\begin{array}{c}7.52 \\
(7.75) \\
\end{array}$ & $\begin{array}{l}20.61 \\
(20.74)\end{array}$ \\
\hline $\begin{array}{c}\mathrm{Al}(\mathrm{S})(\mathrm{Q}) \mathrm{H}_{2} \mathrm{O} \\
{\left[\mathrm{C}_{25} \mathrm{H}_{23} \mathrm{AlN}_{3} \mathrm{O}_{4}\right]^{+} \mathrm{Cl}^{-}}\end{array}$ & 491.95 & $\begin{array}{l}\text { Light yellow } \\
74\end{array}$ & 103.5 & 265 & Dia. & $\begin{array}{c}60.81 \\
(61.04) \\
\end{array}$ & $\begin{array}{c}4.53 \\
(4.71) \\
\end{array}$ & $\begin{array}{c}8.39 \\
(8.54) \\
\end{array}$ & $\begin{array}{c}5.23 \\
(5.49) \\
\end{array}$ \\
\hline $\begin{array}{c}\mathrm{La}(\mathrm{S})(\mathrm{Q}) \mathrm{H}_{2} \mathrm{O} \\
{\left[\mathrm{C}_{25} \mathrm{H}_{21} \mathrm{ClLaN}_{3} \mathrm{O}_{3}\right] \mathrm{H}_{2} \mathrm{O}}\end{array}$ & 603.83 & $\begin{array}{c}\text { Dark yellow } \\
78\end{array}$ & 39.8 & 260 & Dia. & $\begin{array}{c}49.31 \\
(49.73)\end{array}$ & $\begin{array}{l}3.62 \\
(3.84)\end{array}$ & $\begin{array}{c}6.74 \\
(6.96)\end{array}$ & $\begin{array}{l}22.91 \\
(23.00)\end{array}$ \\
\hline
\end{tabular}

\subsection{Molecular Docking Study}

Molecular docking studies were performed using MOA2014 software [32] in order to explore the possible binding modes for the most active site of the receptor of breast cancer oxidoreductase (PDB ID: 3HB5). The crystal structures of the 3HB5 breast cancer receptor were downloaded from the Protein Data Bank (http:/ / www.rcsb.org./pdb accessed date 21 April 2021). The protein was prepared for the docking as follows: (i) The ligand 
molecule was removed from the enzyme active site. (ii) Hydrogen atoms were added to the proteins with MOE and minimized, keeping all the heavy atoms fixed until RMS gradient of $0.01 \mathrm{kcal} / \mathrm{mol}$ and RMS distance of $0.1 \AA$ were reached. (iii) Partial charges were computed using MMFF94x force field. (iv)The structures of salen and its metal complexes were created in PDB file format using the Gaussian09 software package. (v) The structures were subjected to energy minimization using MMFF94x force field, and the partial charges were computed using the same force field. (vi) Docking calculations were performed using Alpha triangle placement method, and poses were ranked by London dG scoring method.

\subsection{PXRD Analysis}

PXRD analysis of the metal complexes was performed using a known standard method [33]. The average crystallite size $(\xi)$ was calculated from the PXRD pattern according to the Debye-Scherrer equation [34,35]

$$
\xi=\frac{\mathrm{K} \lambda}{\beta 1 / 2 \cos \theta}
$$

where $\lambda$ is the wavelength of the X-rays $(1.542475 \AA$ ), $\mathrm{K}$ is a constant taken as 0.95 for organic compounds [34], and $\beta 1 / 2$ is the width at half maximum of the reference diffraction peak measured in radians.

\subsection{Antimicrobial Potency}

The biological activities of the metal complexes were evaluated using two Grampositive bacteria (Bacillus subtilis (+ve) and Staphylococcus aureus (+ve)), two Gram-negative bacteria (Escherichia coli ( - ve) and Proteus vulgaris ( - ve)), and two fungi (Candida albicans and Aspergillus flavus) by the agar diffusion test. In this method, we measured the effectiveness of antibiotics on a specific microorganism. An agar plate was first spread with bacteria, and then paper disks of antibiotics were placed atop of it. The bacteria were then allowed to grow on the agar media and then observed for growth and effect of the antibiotic on it. The amount of space around every antibiotic disk indicated the lethality of that antibiotic on the bacteria in question. Highly active antibiotics will show a large zone of no bacterial development, while an ineffectual antibiotic will display bacterial growth around the disc. The compound under investigation was dissolved in DMSO [36], and paper discs were impregnated with the solution. The disks were dried and set in agar plates containing the microorganisms. Then, the plates were incubated for $25-33 \mathrm{~h}$ at $24 \pm 2{ }^{\circ} \mathrm{C}$, and the inhibition zones, i.e., those where the concentration of the compound exceeds the minimum inhibitory concentration (MIC), were accurately evaluated. Gentamicin as an antibacterial agent and ketoconazole as an antifungal agent were used for comparison.

\subsection{MTT Assay}

The cytotoxic activities of the synthesized ligands and metal complexes against the breast cancer cell line MDA-MB231, the hepatic cellular (Hep-G2), and normal cell line (HEK-293) were assessed by MTT assay. A cell suspension was diluted by complete medium to a concentration of $5 \times 10^{4}$ cell $/ \mathrm{mL}$. Using a micropipette, we pipetted $100 \mu \mathrm{L}$ aliquots of the cell suspension into each well of 96 -well plate $(\approx 5000$ cells/well). The 96-well plate was incubated at $37^{\circ} \mathrm{C}$ for $24 \mathrm{~h}$ to allow cell attachment. After $24 \mathrm{~h}$, cells were treated with $100 \mu \mathrm{L}$ of growth medium containing $0,0.001,0.01,0.1,1,10$, or $100 \mu \mathrm{L}$ of the newly synthesized compounds in triplicate. Cells were washed with phosphate-buffered saline (PBS), and fresh relevant medium containing $20 \mu \mathrm{L}$ MTT in PBS $(0.5 \mathrm{mg} / \mathrm{mL})$ was added to the test wells. The plate was further incubated in a $\mathrm{CO}_{2}$ incubator at $37^{\circ} \mathrm{C}$ for $4 \mathrm{~h}$, and then MTT assay analysis was performed. The MTT assay technique is based on the reduction of the tetrazolium salt MTT to insoluble purple formazan by metabolically active cells, making their activities quantifiable by spectrophotometry. Accordingly, the formed formazan crystals were dissolved in $120 \mu \mathrm{L}$ DMSO for each well. Cell viability was determined by measuring the absorbance of each well at $570 \mathrm{~nm}$ (and at a reference 
wavelength of $630 \mathrm{~nm}$ ) using an ELISA plate reader. Results are expressed in terms of the concentration required to inhibit cell growth by $50 \%$ relative to untreated cells $\left(\mathrm{IC}_{50}\right) . \mathrm{IC}_{50}$ values were calculated using Graph Pad Prism version 6.01, 2012 (GraphPad software, San Diego, CA, USA), by plotting the log concentration versus corresponding viability (\%) to generate dose-response curves.

\section{Results and Discussion}

\subsection{Physicochemical Properties}

All the metal chelates were colored and stable towards air and moisture. The analytical results for the metal complexes were consistent with their proposed molecular formula and confirm the formation of 1:1:1 mixed-ligand salen/8-hydroxyquinoline metal complexes. The values of molar conductance for the metal complexes in $10^{-3} \mathrm{M}$ DMF solutions fell in the range 24.10-53.30 $\Omega^{-1} \mathrm{~cm}^{2} \mathrm{~mol}^{-1}$, except that of AlSQ (103.50). These results demonstrate that the solutions are non-electrolytic except, that of the Al metal complex, which is ionic.

\section{2. ${ }^{1} H$ NMR and ${ }^{13} C$ NMR Spectra}

The NMR of salen [37] and 8-hydroxyquinoline [38,39] were previously studied. Comparing the positions of the proton signals for mixed salen/8-hydroxyquinoline with those for the $\mathrm{Cd}(\mathrm{II})$ and $\mathrm{Al}(\mathrm{III})$ metal complexes shown in (Figure 1A-C and Figure S1), we were able to conclude that all the signals occurred in their expected positions and were shifted only slightly upon the coordination of the salen ligand to the metal ions [40]. The $4 \mathrm{H}$ multiplet signals around 3.87 ppm may be assigned to the ethylene group $\left(\mathrm{CH}_{2} \mathrm{CH}_{2}\right)$ of the salen ligand. These signals appeared at 2.51-2.81 and 3.83-4.05 ppm in the $\left[\mathrm{Cd}(\mathrm{S})(\mathrm{Q})\left(\mathrm{H}_{2} \mathrm{O}\right)\right]$ and $\left[\mathrm{Al}(\mathrm{S})(\mathrm{Q})\left(\mathrm{H}_{2} \mathrm{O}\right)\right]^{+} \mathrm{Cl}^{-}$metal complexes, respectively.

The multiplet signals in the region 6.82-7.54 ppm for the salen ligand may be assigned to aromatic protons [41]. These signals were found at 6.90-7.47 and 6.66-7.36 ppm for $\left[\mathrm{Cd}(\mathrm{S})(\mathrm{Q})\left(\mathrm{H}_{2} \mathrm{O}\right)\right]$ and $\left[\mathrm{Al}(\mathrm{S})(\mathrm{Q})\left(\mathrm{H}_{2} \mathrm{O}\right)\right]^{+} \mathrm{Cl}^{-}$. These signals may also be assigned to quinoline. Other signals appeared at 7.49-8.71 and 7.49-8.62 ppm with an integral value of $6 \mathrm{H}(4 \mathrm{H}$ cyclic, $2 \mathrm{H}$ olefin) for $\left[\mathrm{Cd}(\mathrm{S})(\mathrm{Q})\left(\mathrm{H}_{2} \mathrm{O}\right)\right]$ and $\left[\mathrm{Al}(\mathrm{S})(\mathrm{Q})\left(\mathrm{H}_{2} \mathrm{O}\right)\right]^{+} \mathrm{Cl}^{-}$, respectively, and $1 \mathrm{H} \mathrm{NH}$ for complex $\left[\mathrm{Al}(\mathrm{S})(\mathrm{Q})\left(\mathrm{H}_{2} \mathrm{O}\right)\right]^{+} \mathrm{Cl}$ appeared at $13.34 \mathrm{ppm}$.

The $2 \mathrm{H}$ singlet signal observed at $8.54 \mathrm{ppm}$ for the salen ligand may be assigned to the two $\mathrm{N}=\mathrm{CH}$ protons. This signal slightly shifted to 8.62 and $8.71 \mathrm{ppm}$ for the $\left[\mathrm{Cd}(\mathrm{S})(\mathrm{Q})\left(\mathrm{H}_{2} \mathrm{O}\right)\right]$ and $\left[\mathrm{Al}(\mathrm{S})(\mathrm{Q})\left(\mathrm{H}_{2} \mathrm{O}\right)\right]^{+} \mathrm{Cl}^{-}$metal complexes, respectively. This may be attributed to the coordination of different metal ions through the azomethine group. The singlet signal observed at $13.3 \mathrm{ppm}$ in the ${ }^{1} \mathrm{H}$ NMR spectrum of salen, which corresponded to the phenolic proton, was not observed for the $\left[\mathrm{Cd}(\mathrm{S})(\mathrm{Q})\left(\mathrm{H}_{2} \mathrm{O}\right)\right]$ and $\left[\mathrm{Al}(\mathrm{S})(\mathrm{Q})\left(\mathrm{H}_{2} \mathrm{O}\right)\right]^{+} \mathrm{Cl}^{-}$ metal complexes, while new signals for $\mathrm{NH}$ in the metal complexes were observed at 7.49-8.71 and 7.49-8.62 ppm, respectively (1H for NH Cd and $\mathrm{Al}$ ).

From the ${ }^{1} \mathrm{H}$ NMR results, we found that the metal complexes contained some water molecules, wherein the $2 \mathrm{H}$ signal observed at 3.17 and $3.30 \mathrm{ppm}$ could be assigned to the $\mathrm{OH}$ of $\mathrm{H}_{2} \mathrm{O}$. It may also be concluded that quantum calculation, analytical, and experimental measurements seemed to suggest the proposed structure of the compounds and the different metal ions coordinated with salen through the azomethine nitrogen and phenolic oxygen from one side, and the carbonyl and NH group from the other side. As the $\mathrm{NH}$ group coordinated with the metal ion, salen behaved as a univalent tridentate ligand (Table 2). 

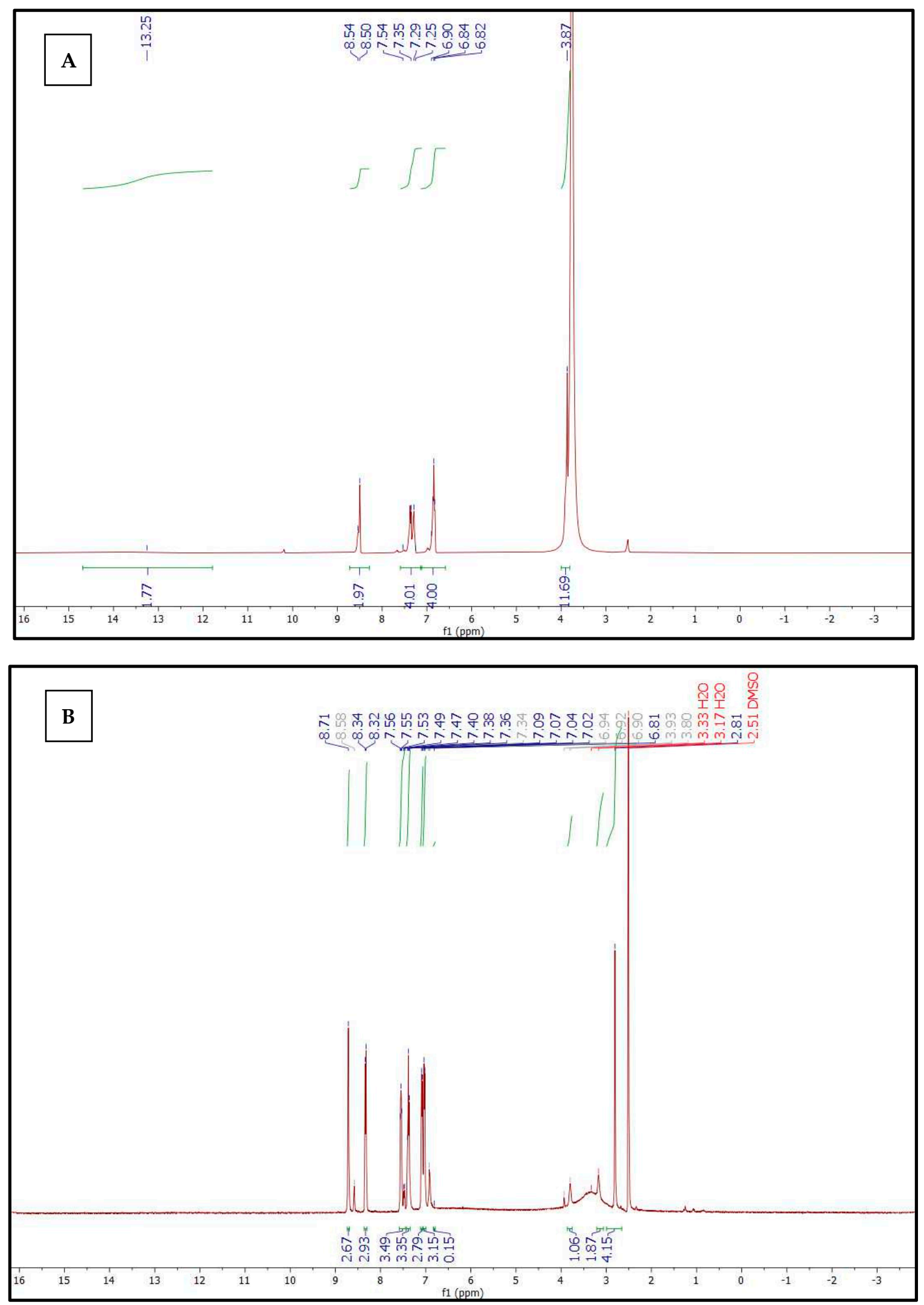

Figure 1. Cont. 


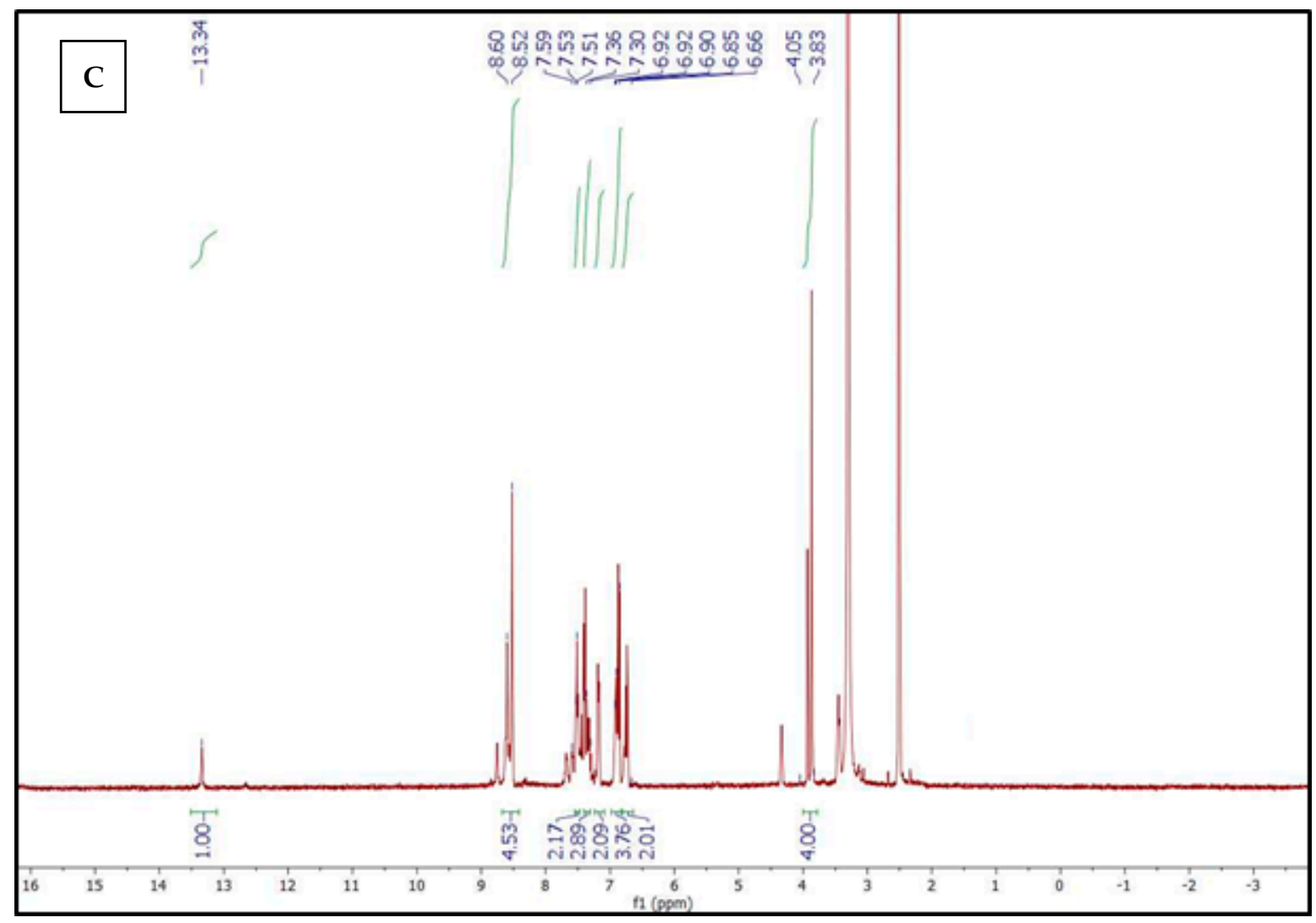

Figure 1. ${ }^{1} \mathrm{H}$ NMR spectrum of salen (A), CdSQ (B), and AlSQ (C) complex in DMSO- $d_{6}$.

Table 2. ${ }^{1} \mathrm{H}$ and ${ }^{13} \mathrm{C}$ NMR data in ppm for mixed-ligand $\mathrm{Cd}(\mathrm{II})$ and $\mathrm{Al}(\mathrm{III})$ metal complexes.

\begin{tabular}{|c|c|c|}
\hline $\begin{array}{c}\text { Metal } \\
\text { Complex }\end{array}$ & ${ }^{1} \mathrm{H}_{\mathrm{NMR}}$ (DMSO-d6/D2O, $\left.400 \mathrm{MHz}\right)$ & ${ }^{13} \mathrm{C} \mathrm{NMR}_{(100 \mathrm{MHz}}$, DMSO-d6) \\
\hline CdSQ & $\begin{array}{c}\left.\text { 2.51-2.81 (t., } 4 \mathrm{H}, \mathrm{Ph}-\mathrm{CH}=\mathrm{N}-\mathrm{CH}_{2}-\mathrm{CH}_{2}-\mathrm{N}\right), 3.17 \\
\text { (br. s., } 2 \mathrm{H}, \mathrm{H}_{2} \mathrm{O} \text { for complex), 3.80-3.93 (br. S., } \\
2 \mathrm{H}, 2 \mathrm{OH}(\mathrm{OH} \text { for hydroxyquinoline+ } \mathrm{OH} \text { for } \\
\text { phenolic ring)), } 6.90-7.47 \text { (m., } 10 \mathrm{H},(\text { phenyl + } \\
\text { quinoline)), } 7.49-8.71(\mathrm{~m} ., 6 \mathrm{H}, 4 \mathrm{H} \text { cyclic }+1 \mathrm{H} \\
\text { olefin+ } 1 \mathrm{H} \text { for } \mathrm{NH})\end{array}$ & $\begin{array}{l}59.21,112.39,113.35,121.80 \\
129.22,129.96,138.10,139.66 \\
146.93,158.98\end{array}$ \\
\hline AlSQ & $\begin{array}{c}3.30 \text { (br. s., } 2 \mathrm{H}, \mathrm{H}_{2} \mathrm{O} \text { for complex), } 3.83-4.05 \\
\left.\text { (t., } 4 \mathrm{H}, \mathrm{Ph}-\mathrm{CH}=\mathrm{N}-\mathrm{CH}_{2}-\mathrm{CH}_{2}-\mathrm{N}\right), 6.66-7.36(\mathrm{~m} ., \\
10 \mathrm{H},(\text { phenyl }+ \text { quinoline })), 7.49-8.62(\mathrm{~m} ., 6 \mathrm{H}, 4 \mathrm{H} \\
\text { cyclic }+2 \mathrm{H} \text { olefin), } 13.34 \text { (br. s., } 1 \mathrm{H} \text { for } \mathrm{NH})\end{array}$ & $\begin{aligned} 53.53, & 56.47,111.88,116.38 \\
120.04, & 121.65,134.58,135.50 \\
& 164.96,167.57\end{aligned}$ \\
\hline
\end{tabular}

Moreover, the ${ }^{13} \mathrm{C}$ NMR spectrum of the salen ligand (Figure S1A) showed signals for two $\mathrm{CH}_{2}$ groups at 58.96, aromatic carbons at 116.99 to 161.19 , and the azomethine group $\mathrm{CH}=\mathrm{N}$ at 167.28. Upon metal complexation with $\mathrm{Cd}$ and Al to form CdSQ and AlSQ, the obtained 13C NMR spectrum (Figure S1B,C) revealed the disappearance of the azomethine group signal and the appearance of signals for cyclic $\mathrm{C}=\mathrm{O}$ at 158.98 and 167.37 , respectively.

When we calculated the energy of 5-coordinated $\mathrm{Cd}$ geometry, the metal complex produced higher energy -1403.037 Hartree, compared to -1479.550 Hartree for the octahedral one. Moreover, 5-coordinated Al metal complex produced higher energy -1357.168 Hartree, compared to -1433.425 Hartree for the octahedral one. Similar results wer found for other metal complexes (Figure S1D,E). 


\subsection{IR Spectra}

The FTIR spectra of salen and its metal complexes are shown in (Figure 2 and Figure S2). The spectrum for salen featured a band at $1608 \mathrm{~cm}^{-1}$, which corresponded to the $-\mathrm{C}=\mathrm{N}$ stretching vibration. Upon the formation of mixed salen/8-hydroxyquinoline metal complexes of $\mathrm{Co}(\mathrm{II}), \mathrm{Ni}(\mathrm{II}), \mathrm{Cd}(\mathrm{II}), \mathrm{Al}(\mathrm{III})$, and $\mathrm{La}(\mathrm{III})$, this band was shifted to a higher frequency $\left(1637,1626,1633,1634\right.$, and $1621 \mathrm{~cm}^{-1}$, respectively). This degree of red shift was evidence of the participation of the azomethine nitrogen atoms in metal complex formation $[33,42,43]$. The salen ligand also presented a band at $1247 \mathrm{~cm}^{-1}$, which was assigned to the $v(\mathrm{C}-\mathrm{O})$ stretching vibration. The coordination of the phenolic oxygen atom was also confirmed by the red shift $\left(1231-1207 \mathrm{~cm}^{-1}\right)$ of the $v(\mathrm{C}-\mathrm{O})$ peak upon metal complex formation. This was supported by the appearance of bands at 445, 441, 494, 485, and $484 \mathrm{~cm}^{-1}$ and bands at 527,538,578,545, and $533 \mathrm{~cm}^{-1}$ corresponding to the stretching vibrations of the $\mathrm{M}-\mathrm{N}$ and $\mathrm{M}-\mathrm{O}$ bonds for the $\mathrm{Co}(\mathrm{II}), \mathrm{Ni}(\mathrm{II}), \mathrm{Cd}(\mathrm{II}), \mathrm{Al}(\mathrm{III})$, and $\mathrm{La}(\mathrm{III})$ metal complexes, respectively.

In the FTIR spectra of the mixed salen/8-hydroxyquinoline metal complexes, the appearance of a band at $1740 \mathrm{~cm}^{-1}$ for all the metal complexes was attributed to the $\mathrm{C}=\mathrm{O}$ stretching vibration, while the bands at $3173,3229,3137,3191$, and $3142 \mathrm{~cm}^{-1}$, respectively, were due to the $\mathrm{NH}$ group. The IR spectra of all the prepared metal chelates showed broad bands at 3432 and $3449 \mathrm{~cm}^{-1}$, which could be assigned to the $v(\mathrm{OH})$ stretching vibration of hydrated water molecules in the mixed-ligand $\mathrm{Ni}(\mathrm{II})$ and $\mathrm{La}(\mathrm{III})$ metal complexes. The IR spectra of the $\mathrm{Co}(\mathrm{II}), \mathrm{Ni}(\mathrm{II}), \mathrm{Cd}(\mathrm{II})$, and $\mathrm{Al}(\mathrm{III})$ metal complexes showed bands at 950, 903, 976 , and $980 \mathrm{~cm}^{-1}$, respectively, which were assigned to the rocking mode of coordinated water (Table 3).

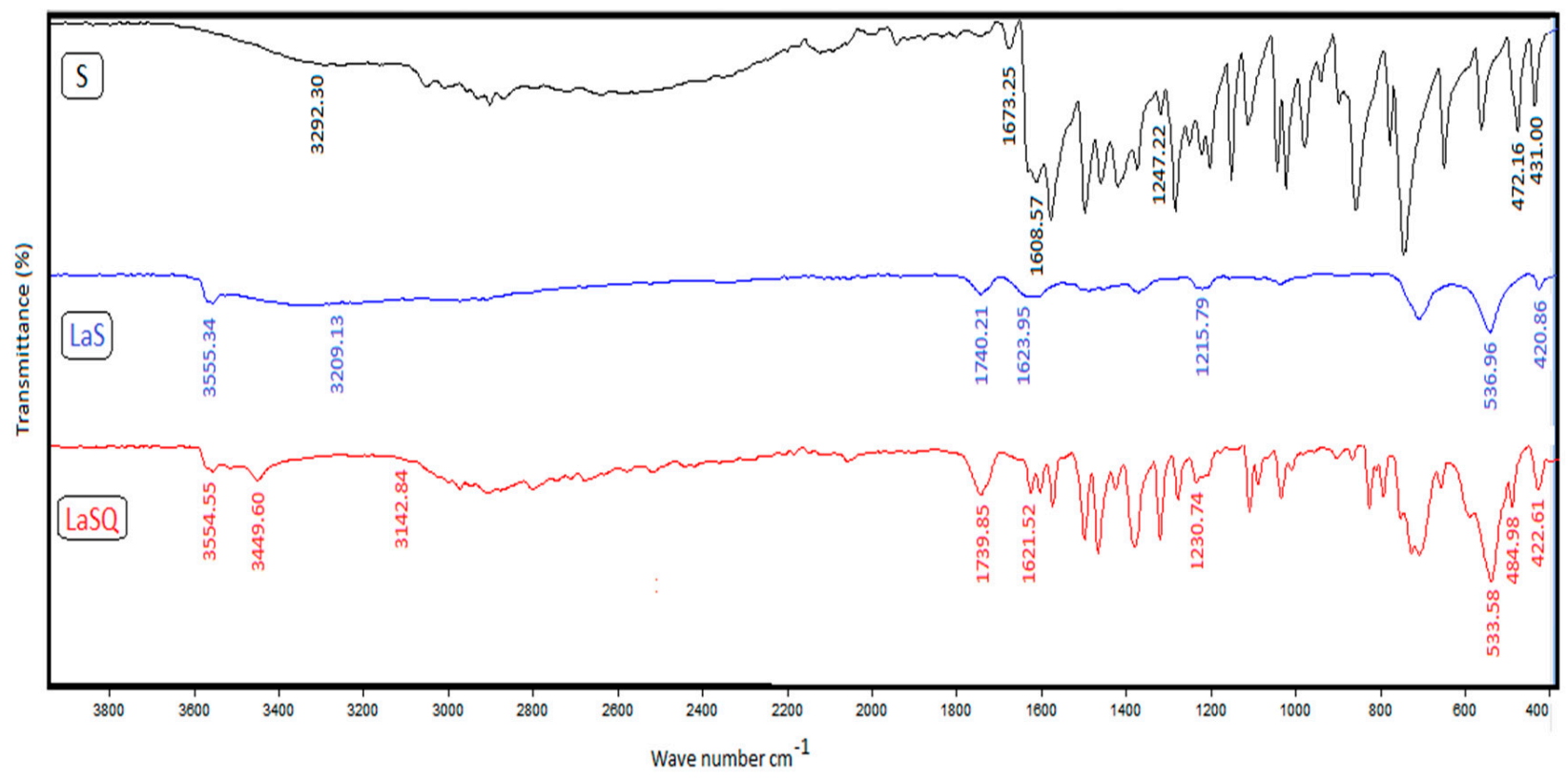

Figure 2. FT-IR spectral of salen Schiff base ligand (S) and its metal complexes (LaS, LaSQ) in 4000-400 $\mathrm{cm}^{-1}$.

Table 3. FTIR spectral data in $\mathrm{cm}^{-1}$ for salen and mixed-ligand salen/8-hydroxyquinoline metal complexes with Co(II), $\mathrm{Ni}(\mathrm{II}), \mathrm{Cd}(\mathrm{II}), \mathrm{Al}(\mathrm{III})$, and $\mathrm{La}(\mathrm{III})$.

\begin{tabular}{|c|c|c|c|c|c|c|c|c|c|c|}
\hline Compound & $v(\mathrm{OH})$ & $v(\mathrm{NH})$ & $v(\mathrm{CH})_{\text {arom }}$ & $v(\mathrm{CH})_{\text {aliph }}$ & $v(\mathrm{C}=\mathrm{O})$ & $v(\mathrm{C}=\mathrm{N})$ & $v(\mathrm{C}-\mathrm{O})$ & $v\left(\mathrm{H}_{2} \mathrm{O}\right)_{\text {Coordinated }}$ & $v(\mathrm{M}-\mathrm{O})$ & $v(\mathrm{M}-\mathrm{N})$ \\
\hline Salen & 3292 & - & 3049-3007 & $2899-2867$ & - & 1608 & 1247 & - & - & - \\
\hline $\operatorname{Cos} Q$ & 3731 & 3173 & 3017 & 2970 & 1740 & 1637 & 1226 & 950 & 527 & 445 \\
\hline NiSQ & 3432 & 3229 & 3049 & $2968-2796$ & 1740 & 1626 & 1213 & 903 & 538 & 441 \\
\hline CdSQ̄ & 3461 & 3137 & 3031 & 2947 & 1740 & 1633 & 1214 & 976 & 578 & 494 \\
\hline AlSQ & 3349 & 3191 & 3008 & $2972-2867$ & 1740 & 1634 & 1207 & 980 & 545 & 485 \\
\hline LaSQ & 3449 & 3142 & 3051 & $2997-2798$ & 1739 & 1621 & 1230 & - & 533 & 484 \\
\hline
\end{tabular}




\subsection{Electronic Spectra}

The UV-VIS spectra of the salen ligand and its metal complexes in DMSO were measured at room temperature in the region $200-700 \mathrm{~nm}$ and are shown in Figure 3. The absorption spectrum of the salen ligand featured three absorption bands at 280, 320, and 409 $\mathrm{nm}$. The first high-intensity band appeared at $\lambda_{\max }=280 \mathrm{~nm}$ may be attributed to the $\pi \rightarrow \pi^{*}$ transition of the aromatic rings. The second and third absorption bands that appeared at $\lambda_{\max }=320$ and $409 \mathrm{~nm}$ can be attributed to the $\mathrm{n} \rightarrow \pi^{*}$ transition of the azomethine group $(\mathrm{C}=\mathrm{N})$ and charge transfer, respectively $[44,45]$.

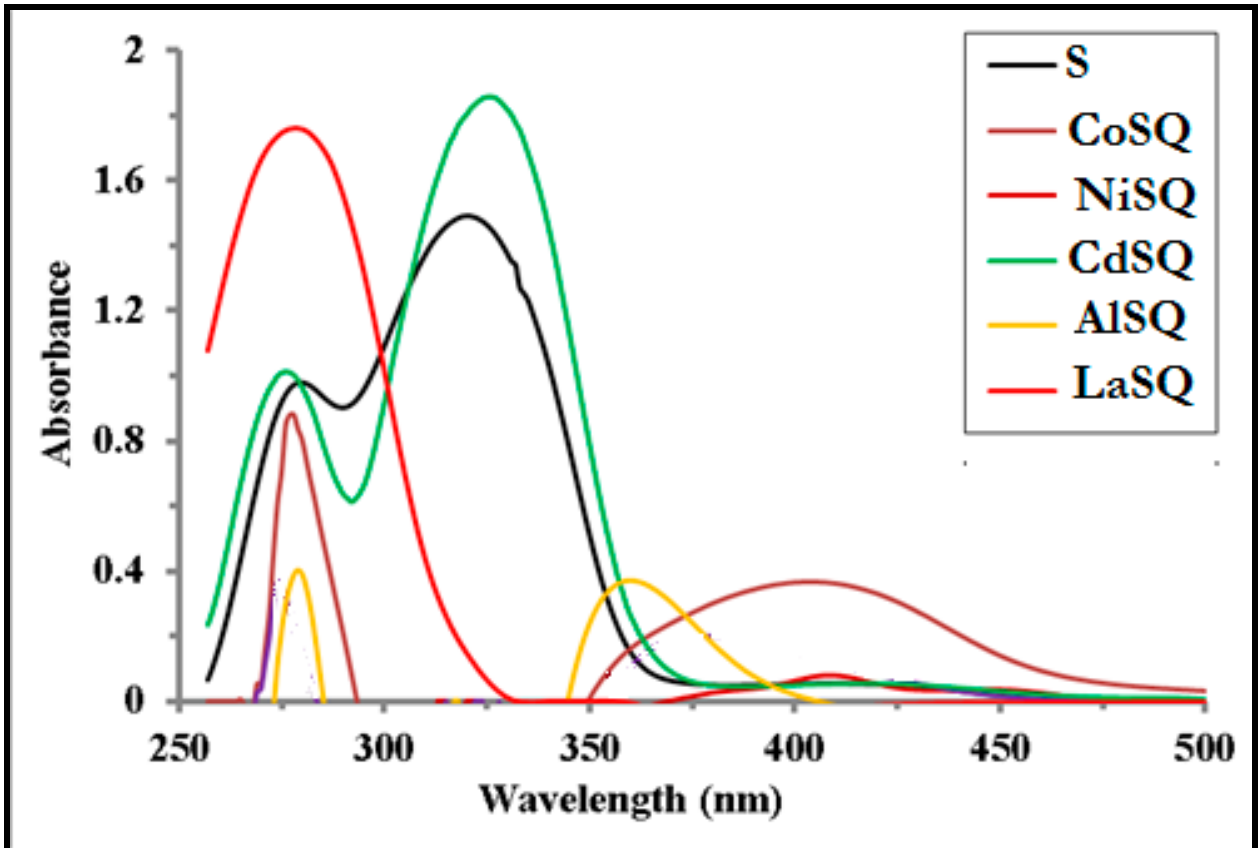

Figure 3. Electronic spectra of the synthesized $\mathrm{Co}(\mathrm{II}), \mathrm{Ni}(\mathrm{II}), \mathrm{Cd}(\mathrm{II}), \mathrm{Al}(\mathrm{III})$, and $\mathrm{La}(\mathrm{III})$ metal complexes of salen/8-hydroxy quinoline in DMSO with concentration $10^{-3} \mathrm{M}$ at $298 \mathrm{~K}$.

Compared to those of the free ligand, the electronic spectra of the metal complexes showed bands that were shifted to 274-291 nm and 304-363 nm for the $\pi \rightarrow \pi^{*}$ and $\mathrm{n} \rightarrow \pi^{*}$ transitions, respectively, confirming the coordination of the azomethine nitrogen to the metal ions. The appearance of a $405 \mathrm{~nm}$ in the Cd(II) metal complex and at $415 \mathrm{~nm}$ for $\mathrm{La}(\mathrm{III})$ metal complex corresponded to charge transfer from ligand to metal LMCT. Furthermore, absorption bands in the visible region at $408 \mathrm{~nm}$ for the Co(II) and $415 \mathrm{~nm}$ for the $\mathrm{Ni}(\mathrm{II})$ metal complexes were observed. These bands were considered to arise from $\mathrm{d}-\mathrm{d}$ transitions [46].

\section{5. $p H$ Profiles}

The $\mathrm{pH}$ profiles (i.e., absorbance vs. $\mathrm{pH}$ ) shown in Figure 4 exhibited typical dissociation curves and revealed high stabilities in the $\mathrm{pH}$ range 5-10 for the chelates of $\mathrm{Co}$ (II) and $\mathrm{Cd}(\mathrm{II}), 6-10$ for $\mathrm{Ni}(\mathrm{II}), 5-11$ for $\mathrm{Al}(\mathrm{III})$, and 6-11 for $\mathrm{La}(\mathrm{III})$. This revealed that the formation of the metal chelate greatly stabilized the ligands. Consequently, a suitable $\mathrm{pH}$ range for the application of the resultant mixed-ligand metal chelates was found to be 5-11. 


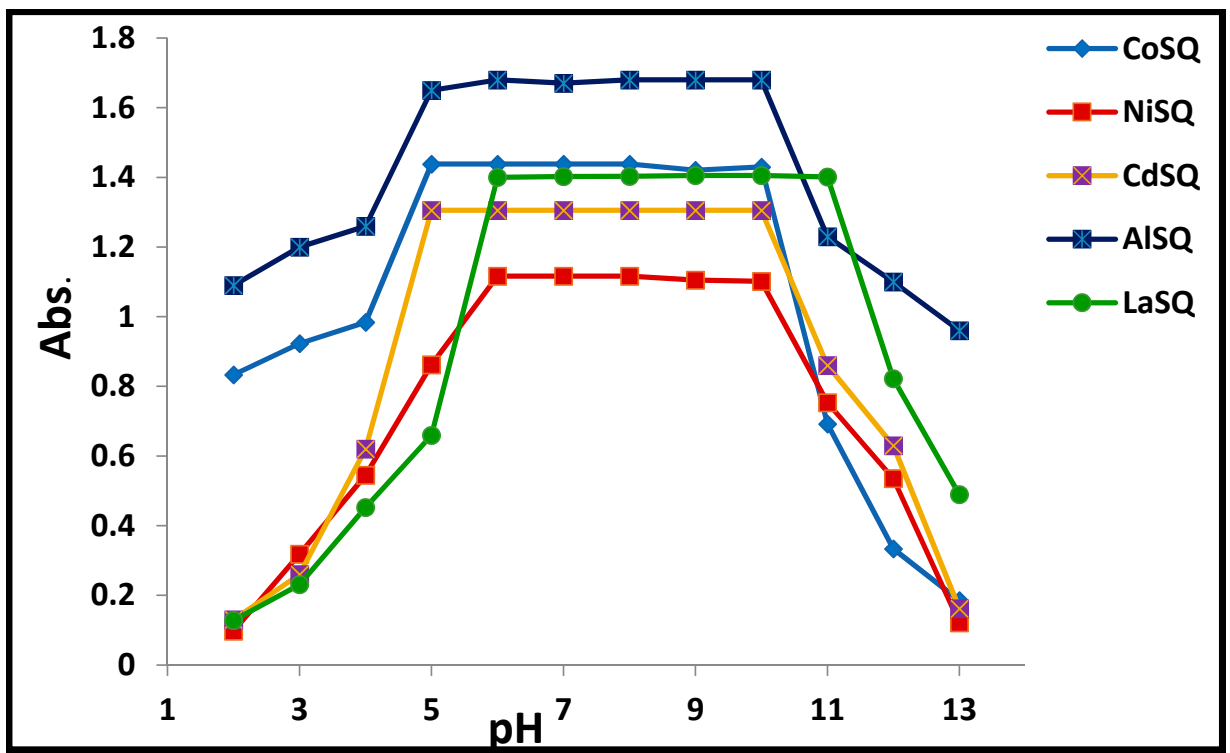

Figure 4. Dissociation curve of the mixed ligand metal complexes in DMSO.

\subsection{ESI-MS Spectra}

MS has become increasingly used for elucidation of the molecular structures of ligands and their metal complexes. The mass spectra of salen and its mixed 8-hydroxyquinoline metal complexes of $\mathrm{Co}(\mathrm{II}), \mathrm{Ni}(\mathrm{II}), \mathrm{Cd}(\mathrm{II}), \mathrm{Al}(\mathrm{III})$, and $\mathrm{La}(\mathrm{III})$ showed molecular ion peaks at $m / z 269.07$ for salen and at $m / z 488.40,497.16,541.88,491.95$, and 603.83 for its metal complexes, respectively. These data are in good agreement with the proposed molecular formulae. The ESI-MS spectra of the metal complexes are shown in Figure 5 and Figure S3. The suggested fragmentation pattern for CdSQ is shown in Scheme S2.

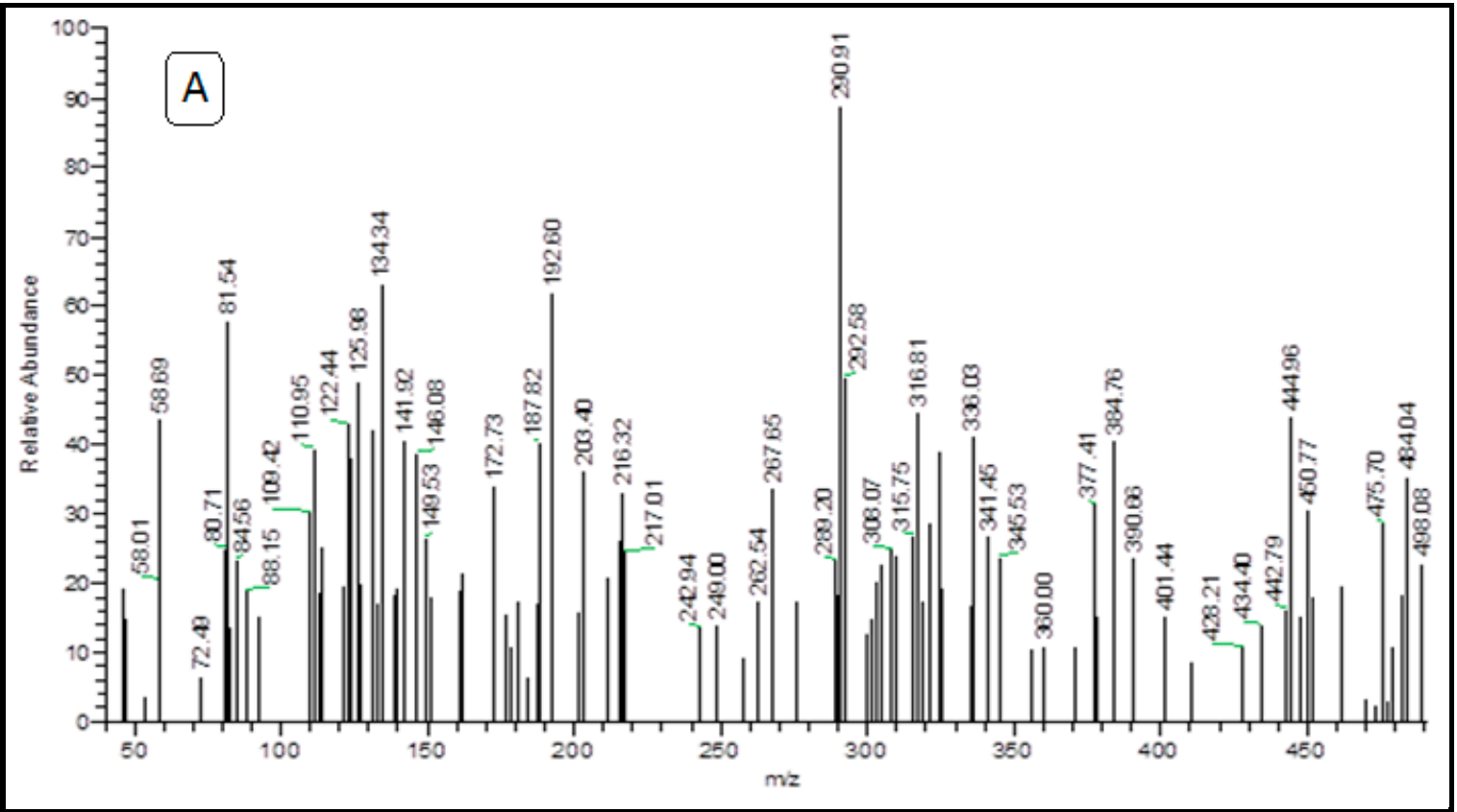

Figure 5. Cont. 


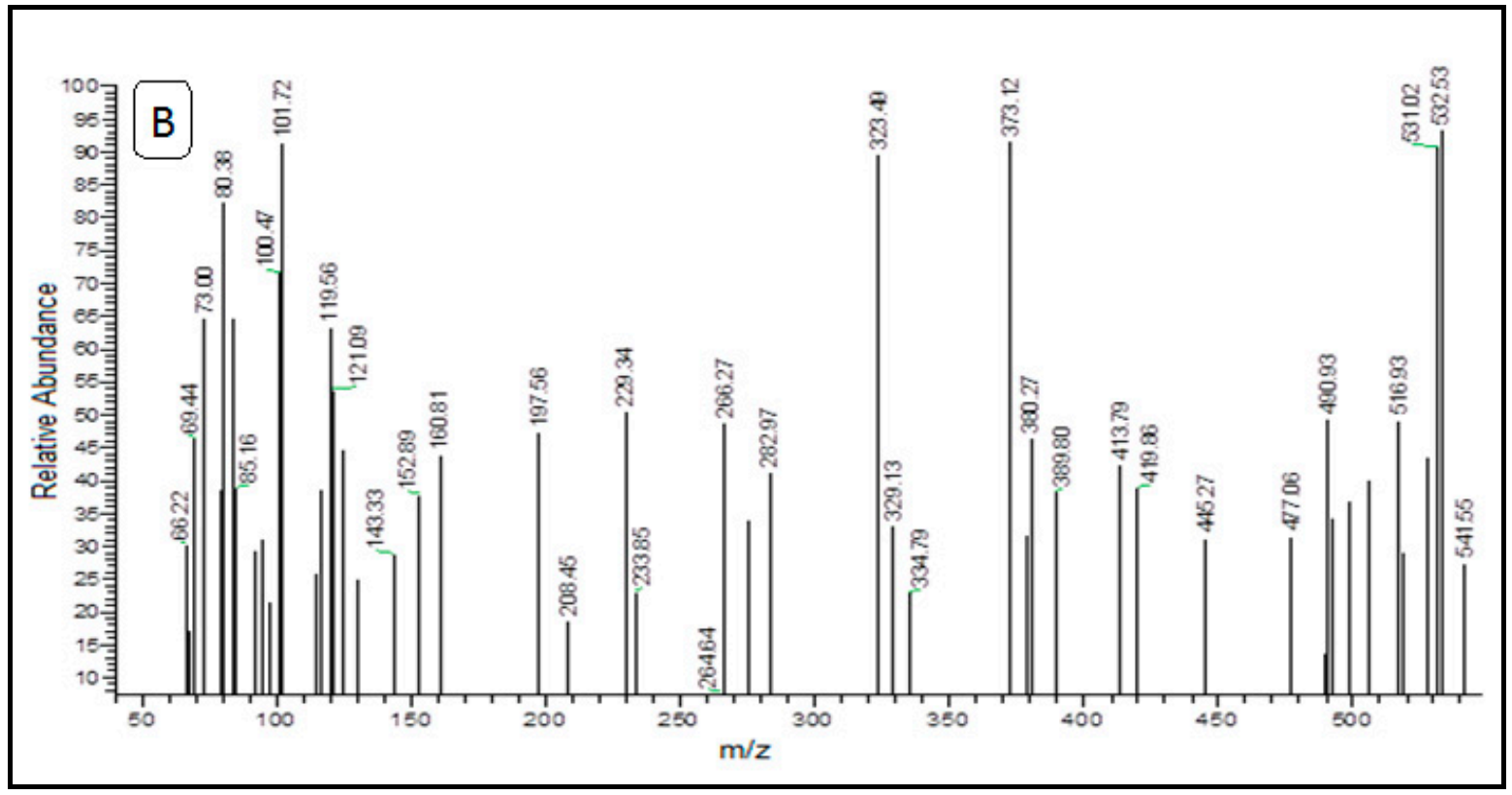

Figure 5. The mass spectrum of (A) NiSQ and (B) CdSQ mixed ligand metal complexes.

\subsection{PXRD Analysis}

The growth of single crystals of the synthesized compounds failed, and hence PXRD was performed. The powder diffraction patterns of salen and metal complexes of $\mathrm{Cd}$ (II) and $\mathrm{La}(\mathrm{III})$ with salen and mixed salen/8-hydroxyquinoline were recorded over the $2 \theta$ range $5^{\circ}-70^{\circ}$ range (Table 4 ). The position of the highest intensity peak was determined, along with the width of this peak at half maximum and the d-spacing. The diffractograms of the ligand and metal complexes are shown in Figure 6 and Figure S4. The diffractogram of the salen ligand featured a reflection with its maxima at $2 \theta=13.14^{\circ}$ corresponding to a d-spacing value of 6.7318 .

The PXRD patterns of the metal complexes were completely different from that of salen, demonstrating the formation of the coordination compounds. The diffraction pattern revealed well-defined crystalline peaks, indicating the crystalline nature of salen and the CdSQ and LaSQ metal complexes. The average particle size of the crystalline metal complexes was calculated using Scherrer's formula. The average particle sizes for salen ligand and its $\mathrm{Cd}$ (II) and $\mathrm{La}(\mathrm{III})$ mixed 8-hydroxyquinoline metal complexes were calculated to be $0.521,0.423$, and $0.343 \mathrm{~nm}$, respectively.

Table 4. PXRD data for salen and mixed-ligand salen/8-hydroxyquinoline metal complexes of $\mathrm{Cd}$ (II) and $\mathrm{La}(\mathrm{III})$.

\begin{tabular}{cccccc}
\hline \multirow{2}{*}{ Compounds } & \multicolumn{5}{c}{ Crystallographic Parameters } \\
\cline { 2 - 6 } & Crystal System & $\mathbf{D}(\mathbf{n m})$ & $\mathbf{a}(\mathbf{n m})$ & $\mathbf{b} \mathbf{( n m})$ & $\mathbf{c}(\mathbf{n m})$ \\
\hline CdS & Monoclinic & 49.93 & 6.98 & 14.90 & 10.41 \\
CdSQ & Triclinic & 38.55 & 9.01 & 11.16 & 13.24 \\
LaS & Monoclinic & 77.08 & 7.56 & 25.72 & 8.17 \\
LaSQ & Monoclinic & 62.23 & 10.39 & 10.22 & 8.70 \\
Salen & Monoclinic & 95.98 & 9.80 & 8.78 & 17.24 \\
\hline
\end{tabular}



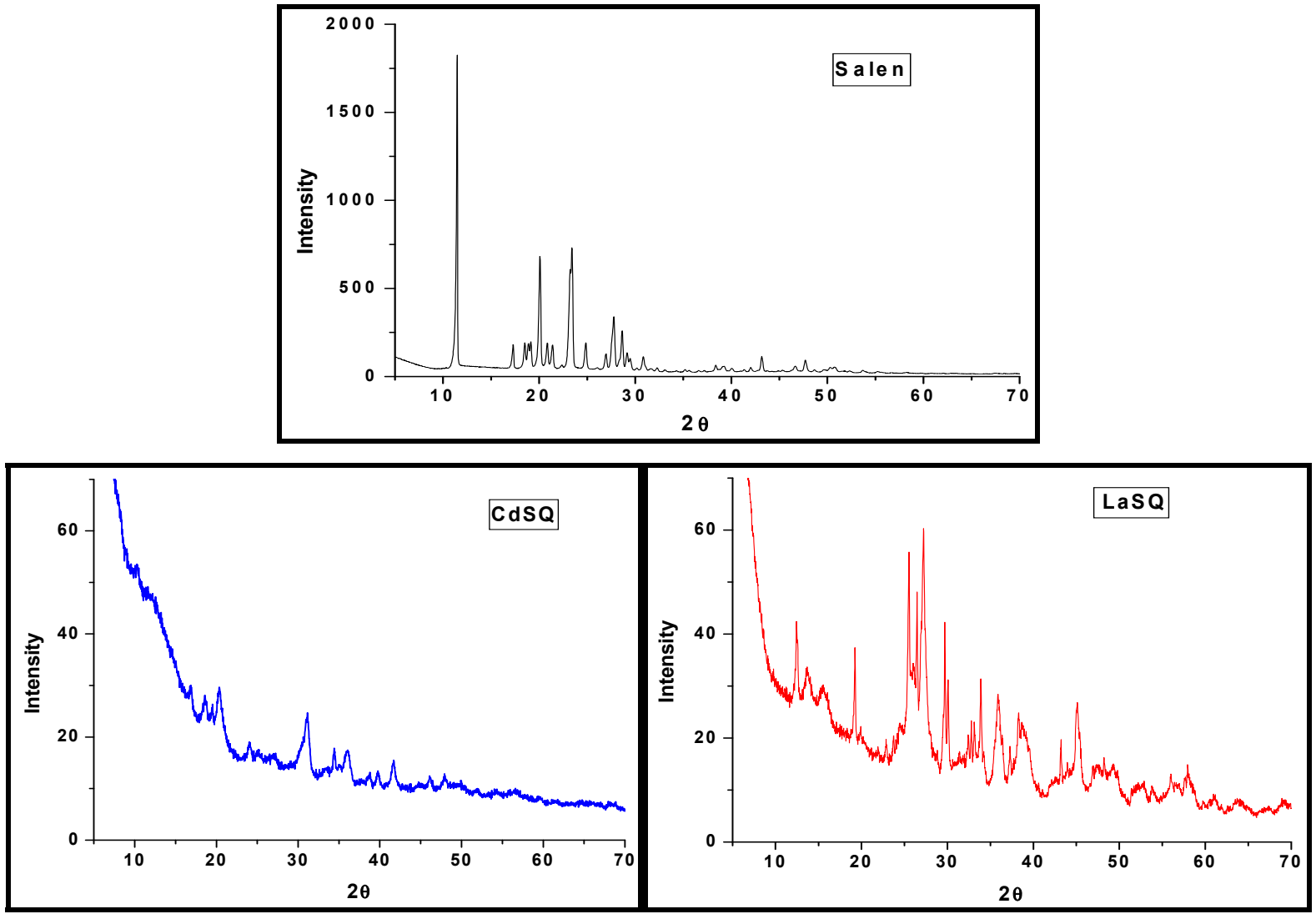

Figure 6. PXRD powder pattern of salen and its mixed CdSQ and LaSQ metal complexes with 8-hydroxyquinolone.

\subsection{Thermogravimetric Analysis}

The stepwise decompositions of the resultant metal complexes with respect to temperature and the formation of the respective metal are depicted in Figure 7 and Figure S5. The thermograms of the metal chelates indicated the presence of one coordinated water molecule in all the metal complexes except LaSQ, which contained one hydrated water molecule, and NiSQ, which contained a half equivalent hydrated water molecule.

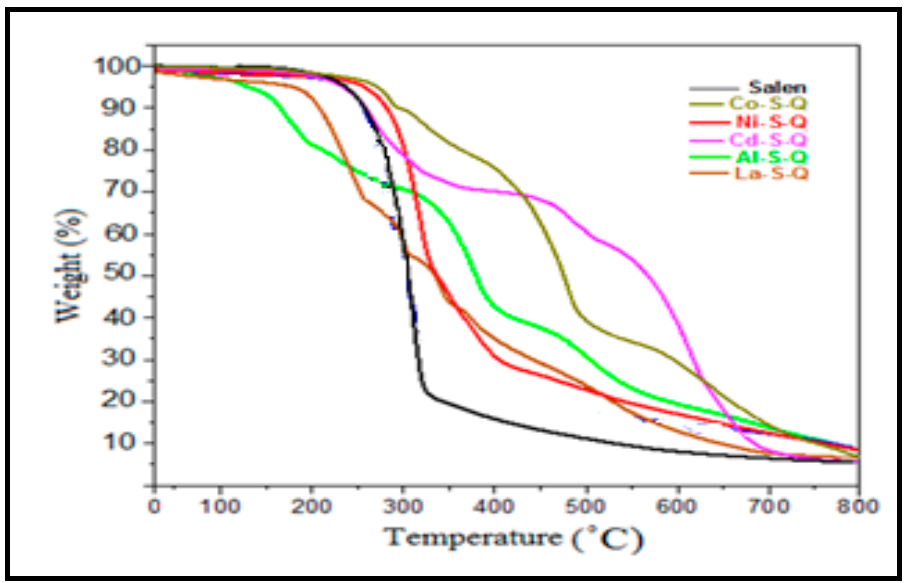

Figure 7. TGA curves for thermal degradation of salen/8-hydroxyquinoline ligand and its $\operatorname{Co}(\mathrm{II})$, $\mathrm{Ni}(\mathrm{II}), \mathrm{Cd}(\mathrm{II}), \mathrm{Al}(\mathrm{III})$, and $\mathrm{La}(\mathrm{III})$ metal complexes from ambient temperature to $800{ }^{\circ} \mathrm{C}$ at a heating rate of $10^{\circ} \mathrm{C} / \mathrm{min}$. 
The thermal degradation of the hydrated metal chelates involves the loss of hydration water molecules followed by loss of coordinated water molecules and degradation of the ligand molecules in later stages, as displayed in Table 5 and Scheme 2 and Scheme S1.

Table 5. Thermogravimetric analysis results for mixed salen/8-hydroxyquinoline metal complexes from ambient temperature to $800^{\circ} \mathrm{C}$ and heating rate of $10^{\circ} \mathrm{C} / \mathrm{min}$.

\begin{tabular}{|c|c|c|c|}
\hline Compounds & Temp. Range ${ }^{\circ} \mathrm{C}$ & $\begin{array}{l}\text { Weight Lost.\% calc } \\
\text { (Found) }\end{array}$ & Assignments \\
\hline $\operatorname{CoSQ}$ & $100-250$ & \multirow{2}{*}{$3.65(3.68)$} & $\mathrm{H}_{2} \mathrm{O}$ \\
\hline \multirow{5}{*}{$\mathrm{C}_{25} \mathrm{H}_{23} \mathrm{CoN}_{3} \mathrm{O}_{4}$} & $250-290$ & & $\mathrm{C}_{2} \mathrm{H}_{4}$ \\
\hline & $290-395$ & $5.70(5.73)$ & $\mathrm{C}_{4} \mathrm{H}_{2} \mathrm{~N}$ \\
\hline & $395-490$ & $13.15(13.10)$ & $\mathrm{C}_{10} \mathrm{H}_{6} \mathrm{NO}$ \\
\hline & $490-580$ & $31.90(31.94)$ & $\mathrm{C}_{4} \mathrm{H}_{4}$ \\
\hline & $580-740$ & $10.60(10.64)$ & $\mathrm{C}_{5} \mathrm{H}_{5} \mathrm{NO}_{2}$ \\
\hline Residue & $>740$ & & Co \\
\hline \multirow{4}{*}{$\frac{\mathrm{NiSQ}}{\left[\mathrm{C}_{25} \mathrm{H}_{23} \mathrm{~N}_{3} \mathrm{NiO}_{4}\right] 0.5 \mathrm{H}_{2} \mathrm{O}}$} & $25-260$ & \multirow{5}{*}{$\begin{array}{c}3.70(5.43) \\
41.85(41.80) \\
26.61(26.63) \\
15.65(15.77)\end{array}$} & $3 / 2 \mathrm{H}_{2} \mathrm{O}$ \\
\hline & $260-320$ & & $\mathrm{C}_{11} \mathrm{H}_{12} \mathrm{~N}_{2} \mathrm{O}_{2}$ \\
\hline & $320-400$ & & $\mathrm{C}_{8} \mathrm{H}_{4} \mathrm{NO}$ \\
\hline & $400-620$ & & $\mathrm{C}_{6} \mathrm{H}_{5}$ \\
\hline Residue & $>620$ & & $\mathrm{Ni}$ \\
\hline \multirow{4}{*}{$\begin{array}{c}\mathrm{CdSQ} \\
\mathrm{C}_{25} \mathrm{H}_{23} \mathrm{CdN}_{3} \mathrm{O}_{4}\end{array}$} & $35-200$ & \multirow{5}{*}{$\begin{aligned} 3.30 & (3.32) \\
21.38 & (21.44) \\
6.10 & (5.54) \\
48.47 & (48.90)\end{aligned}$} & $\mathrm{H}_{2} \mathrm{O}$ \\
\hline & $200-340$ & & $\mathrm{C}_{5} \mathrm{H}_{10} \mathrm{NO}_{2}$ \\
\hline & $340-465$ & & $\mathrm{CH}_{2} \mathrm{O}$ \\
\hline & $465-655$ & & $\mathrm{C}_{19} \mathrm{H}_{9} \mathrm{~N}_{2}$ \\
\hline Residue & $>665$ & & $\mathrm{Cd}$ \\
\hline \multirow{5}{*}{$\begin{array}{c}\mathrm{AlSQ} \\
{\left[\mathrm{C}_{25} \mathrm{H}_{23} \mathrm{AlN}_{3} \mathrm{O}_{4}\right]^{+} \mathrm{Cl}^{-}}\end{array}$} & 90-200 & \multirow{6}{*}{$\begin{array}{c}19.9(20.42) \\
14.20(14.34) \\
25.85(26.01) \\
10.55(10.57) \\
22.72(22.69)\end{array}$} & $\mathrm{H}_{2} \mathrm{O}, \mathrm{HCl}, \mathrm{NO}_{2}$ \\
\hline & $200-325$ & & $\mathrm{C}_{3} \mathrm{H}_{5} \mathrm{NO}$ \\
\hline & $325-400$ & & $\mathrm{C}_{9} \mathrm{H}_{6} \mathrm{~N}$ \\
\hline & $400-490$ & & $\mathrm{C}_{4} \mathrm{H}_{4}$ \\
\hline & $490-710$ & & $\mathrm{C}_{9} \mathrm{H}_{5}$ \\
\hline Residue & $>710$ & & $\mathrm{Al}$ \\
\hline \multirow{6}{*}{$\frac{\mathrm{LaSQ}}{\left[\mathrm{C}_{25} \mathrm{H}_{21} \mathrm{ClLaN}_{3} \mathrm{O}_{3}\right] \mathrm{H}_{2} \mathrm{O}}$} & $35-200$ & \multirow{7}{*}{$\begin{array}{c}3.32(2.98) \\
21.31(21.28) \\
8.81(8.61) \\
7.40(7.28) \\
5.10(4.97) \\
30.96(31.79)\end{array}$} & $\mathrm{H}_{2} \mathrm{O}$ \\
\hline & $200-265$ & & $\mathrm{C}_{5} \mathrm{H}_{3} \mathrm{NOCl}$ \\
\hline & $265-320$ & & $\mathrm{C}_{4} \mathrm{H}_{4}$ \\
\hline & $320-360$ & & $\mathrm{~N}_{2} \mathrm{O}$ \\
\hline & $360-385$ & & $\mathrm{CH}_{2} \mathrm{O}$ \\
\hline & $385-625$ & & $\mathrm{C}_{15} \mathrm{H}_{12}$ \\
\hline Residue & $>625$ & & $\mathrm{La}$ \\
\hline
\end{tabular}

$$
\begin{aligned}
& {\left[\mathrm{C}_{25} \mathrm{H}_{23} \mathrm{~N}_{3} \mathrm{O}_{4} \mathrm{Co}\right] \frac{100^{\circ} \mathrm{C}-250^{\circ} \mathrm{C}}{-\mathrm{H}_{2} \mathrm{O}}-\left[\mathrm{C}_{25} \mathrm{H}_{21} \mathrm{~N}_{3} \mathrm{O}_{3} \mathrm{Co}\right] \frac{250^{\circ} \mathrm{C}-290^{\circ} \mathrm{C}}{-\mathrm{C}_{2} \mathrm{H}_{4}}-\left[\mathrm{C}_{23} \mathrm{H}_{17} \mathrm{~N}_{3} \mathrm{O}_{3} \mathrm{Co}\right] \frac{290^{\circ} \mathrm{C}-395^{\circ} \mathrm{C}}{-\mathrm{C}_{4} \mathrm{H}_{2} \mathrm{~N}}} \\
& {\left[\mathrm{C}_{19} \mathrm{H}_{15} \mathrm{~N}_{2} \mathrm{O}_{3} \mathrm{Co}\right] \frac{395^{\circ} \mathrm{C}-490^{\circ} \mathrm{C}}{-\mathrm{C}_{10} \mathrm{H}_{6} \mathrm{NO}}-\left[\mathrm{C}_{9} \mathrm{H}_{9} \mathrm{NO}_{2} \mathrm{Co}\right] \stackrel{490^{\circ} \mathrm{C}-580^{\circ} \mathrm{C}}{-\mathrm{C}_{4} \mathrm{H}_{4}}-\left[\mathrm{C}_{5} \mathrm{H}_{5} \mathrm{NO}_{2} \mathrm{Co}\right] \frac{580^{\circ} \mathrm{C}-740^{\circ} \mathrm{C}}{-\mathrm{C}_{5} \mathrm{H}_{5} \mathrm{NO}_{2}}-\mathrm{Co}}
\end{aligned}
$$

Scheme 2. Thermogravimetric degradation steps for the new mixed CoSQ metal complex from ambient temperature to $800{ }^{\circ} \mathrm{C}$ at a heating rate of $10^{\circ} \mathrm{C} / \mathrm{min}$.

The thermograms of the CoSQ and LaSQ metal complexes showed six decomposition steps within the temperature range $35-740{ }^{\circ} \mathrm{C}$. The first steps of degradation within the temperature range $35-250{ }^{\circ} \mathrm{C}$ corresponded to the loss of coordinated and hydrated water molecules with mass losses of $3.65 \%$ and $3.32 \%$ (calc. $3.68 \%$ and $2.98 \%$ ), respectively. The second steps of decomposition occurred within the temperature range $200-290{ }^{\circ} \mathrm{C}$ with mass losses of $5.70 \%$ and $21.31 \%$ (calc. $5.73 \%$ and $21.28 \%$ ) that indicated the removal of $\mathrm{C}_{2} \mathrm{H}_{4}$ and $\mathrm{C}_{5} \mathrm{H}_{3} \mathrm{NOCl}$, respectively. The third stages occurred in the temperature range $265-395{ }^{\circ} \mathrm{C}$ with mass losses of $13.15 \%$ and $8.81 \%$ (calc. $13.10 \%$ and $8.61 \%$ ), respectively. 
This corresponded to loss of $\mathrm{C}_{4} \mathrm{H}_{2} \mathrm{~N}$ and $\mathrm{C}_{4} \mathrm{H}_{4}$, respectively. The fourth stages occurred in the temperature range $320-490{ }^{\circ} \mathrm{C}$ with mass losses of $31.90 \%$ and $7.40 \%$ (calc. $31.94 \%$ and $7.28 \%$ ), respectively. This corresponded to loss of $\mathrm{C}_{10} \mathrm{H}_{6} \mathrm{NO}$ and $\mathrm{N}_{2} \mathrm{O}$, respectively. The fifth stages occurred in the temperature range $360-580{ }^{\circ} \mathrm{C}$ with mass losses of $10.60 \%$ and $5.10 \%$ (calc. $10.64 \%$ and $4.97 \%$ ), respectively. This corresponded to loss of $\mathrm{C}_{4} \mathrm{H}_{4}$ and $\mathrm{CH}_{2} \mathrm{O}$, respectively. The sixth stages occurred in the temperature range $385-740{ }^{\circ} \mathrm{C}$ with mass losses of $22.74 \%$ and $30.96 \%$ (calc. $22.72 \%$ and $31.79 \%$ ), respectively. This corresponded to loss of $\mathrm{C}_{5} \mathrm{H}_{5} \mathrm{NO}_{2}$ and $\mathrm{C}_{15} \mathrm{H}_{12}$, leaving $\mathrm{Co}$ and $\mathrm{La}$ as residues, respectively.

The thermograms of the NiSQ, and CdSQ metal complexes showed four decomposition steps in the temperature range $25-665^{\circ} \mathrm{C}$. The first steps of degradation from 25 to $240{ }^{\circ} \mathrm{C}$ corresponded to the loss of hydrated and coordinated water molecules with mass losses of $3.70 \%$, and $3.30 \%$ (calc. $5.43 \%$, and $3.32 \%$ ), respectively. The second steps of decomposition within the temperature range $200-340{ }^{\circ} \mathrm{C}$ with mass losses of $41.85 \%$, and $21.38 \%$ (calc. $41.80 \%$, and $21.44 \%$ ) indicate the removal of $\mathrm{C}_{11} \mathrm{H}_{12} \mathrm{~N}_{2} \mathrm{O}_{2}$, and $\mathrm{C}_{5} \mathrm{H}_{10} \mathrm{NO}_{2}$, respectively. The third stages in the temperature range $290-465{ }^{\circ} \mathrm{C}$ with mass losses of $26.61 \%$, and $6.10 \%$ (calc. $26.63 \%$, and $5.54 \%$ ) corresponded to loss of $\mathrm{C}_{8} \mathrm{H}_{4} \mathrm{NO}$, and $\mathrm{CH}_{2} \mathrm{O}$, respectively. The fourth stages in the temperature range $315-655{ }^{\circ} \mathrm{C}$ with mass losses of $15.65 \%$, and $48.47 \%$ (calc. $15.77 \%$, and $48.90 \%$ ) corresponded to loss of $\mathrm{C}_{6} \mathrm{H}_{5}$, and $\mathrm{C}_{19} \mathrm{H}_{9} \mathrm{~N}_{2}$, leaving $\mathrm{Ni}$, and $\mathrm{Cd}$ as residues, respectively.

The thermogram of the AlSQ metal complex showed five decomposition steps within the temperature range $90-710^{\circ} \mathrm{C}$. The first step of degradation within the temperature range $90-200{ }^{\circ} \mathrm{C}$ corresponded to the loss of a coordinated water molecule, hydrogen chloride, and nitrogen dioxide with a mass loss of $19.9 \%$ (calc. $20.42 \%$ ). The second step of decomposition within the temperature range $200-325{ }^{\circ} \mathrm{C}$ with a mass loss of $14.20 \%$ (calc. $14.34 \%$ ) indicated the removal of $\mathrm{C}_{3} \mathrm{H}_{5} \mathrm{NO}$. The third stage in the temperature range $325-400{ }^{\circ} \mathrm{C}$ with a mass loss of $25.85 \%$ (calc. $26.01 \%$ ) corresponded to loss of $\mathrm{C}_{9} \mathrm{H}_{6} \mathrm{~N}$. The fourth stage in the temperature range $400-490{ }^{\circ} \mathrm{C}$ with a mass loss of $10.55 \%$ (calc. $10.57 \%$ ) corresponded to loss of $\mathrm{C}_{4} \mathrm{H}_{4}$. The fifth stage in the temperature range $490-410{ }^{\circ} \mathrm{C}$ with a mass loss of $22.72 \%$ (calc. $22.69 \%$ ) corresponded to loss of $\mathrm{C}_{9} \mathrm{H}_{5}$, The sixth stage in the temperature range $580-740{ }^{\circ} \mathrm{C}$ with a mass loss of $22.74 \%$ (calc. $22.72 \%$ ) corresponded to loss of $\mathrm{C}_{5} \mathrm{H}_{5} \mathrm{NO}_{2}$, leaving $\mathrm{Co}$ as a residue.

\subsection{DFT Analysis}

\subsubsection{Molecular DFT Calculation of Salen}

The ligand has two isomers, keto-enol form (A) and enol-enol form (B) (Figure 8). The keto-enol form is more stable than enol-enol form by -0.0073 Hartree, $-0.1986 \mathrm{ev}$, $-4.5808 \mathrm{kcal} / \mathrm{mol}$, or $-19.1661 \mathrm{~kJ} / \mathrm{mol}$. The hydrogen bond between $\mathrm{C}=\mathrm{O}$ and $\mathrm{N}-\mathrm{H}$ is shorter (stronger) in (A) than the hydrogen bond between $\mathrm{O}-\mathrm{H}$ and $\mathrm{N}$ in (B).

Figure 8, shows the optimized structures of the ligand (A) as the lowest energy configurations. The natural charges obtained from natural bond orbital analysis (NBO) show that the more negative active sites are in the order of $\mathrm{O} 2(-0.728)>\mathrm{O} 1(-0.720)>\mathrm{N} 1$ $(-0.488)>\mathrm{N} 2(+0.583)$. Thus, the metal ions prefer tridentate coordination to $\mathrm{O} 2, \mathrm{~N} 1$, and N2, forming stable 5- and 6-membered rings [37].

Figure 9 and Table 6 show the optimized structures and some selected bond distances and angles of the mixed-ligand metal complexes.

\subsection{2. $\left[\mathrm{Co}(\mathrm{S})(\mathrm{Q})\left(\mathrm{H}_{2} \mathrm{O}\right)\right]$}

Figure 9A shows the optimized structures of the metal complex $\left.\left[\mathrm{Co}(\mathrm{S})(\mathrm{Q}) \mathrm{H}_{2} \mathrm{O}\right)\right]$ as the lowest-energy configurations. The Co atom is six-coordinate in an octahedral geometry, with N1, N2, N3, and O4 being coplanar with a $6.999^{\circ}$ deviation (Table S3).

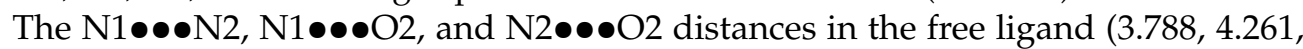
and $7.003 \AA$ ) are longer than those in the metal complex $(2.709,2.720$, and $3.045 \AA)$ due to metal complex formation through $\mathrm{N} 1, \mathrm{~N} 2$, and $\mathrm{O} 2$. 
The natural charges on the coordinated atoms as calculated using natural bond orbital (NBO) analysis are Co (+0.409), O2 (-0.650), N1 (-0.487), N2 (-0.653), N4 (-0.498), N5 $(-0.490)$, and $\mathrm{Cl}(-0.433)$.

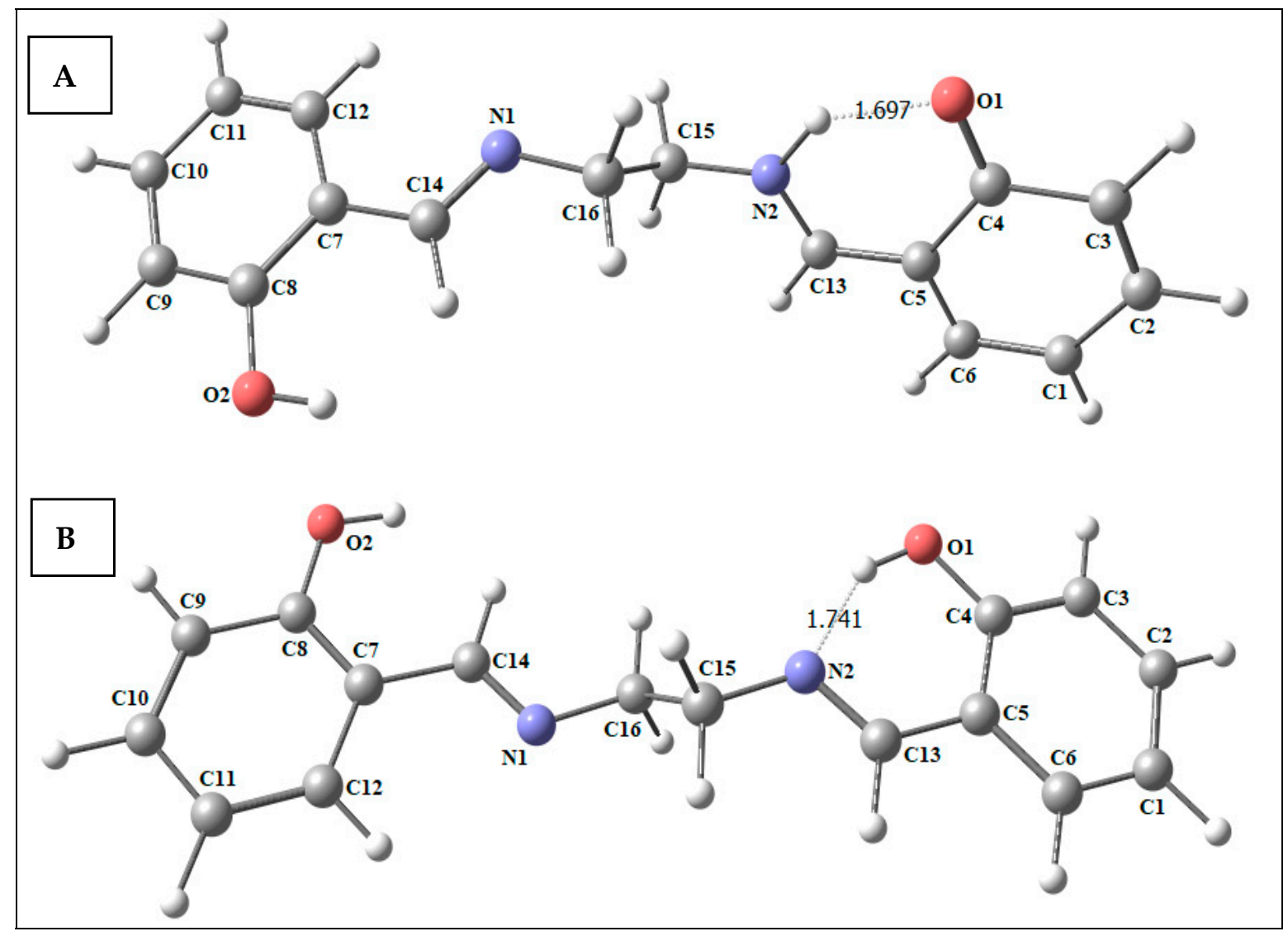

Figure 8. The optimized structure of the keto-enol (A) and the enol-enol (B) by density function B3LYP/6-311++g(d,p).

\subsection{3. $\left[\mathrm{Ni}(\mathrm{S})(\mathrm{Q})\left(\mathrm{H}_{2} \mathrm{O}\right)\right]$}

Figure $9 \mathrm{~B}$ shows the optimized structures of the metal complex $\left[\mathrm{Ni}(\mathrm{S})(\mathrm{Q})\left(\mathrm{H}_{2} \mathrm{O}\right)\right]$ as the lowest-energy configurations. The $\mathrm{Ni}$ atom is six-coordinate in an octahedral geometry, with $\mathrm{N} 1, \mathrm{~N} 2$, N3, and $\mathrm{O} 4$ being coplanar with a $-3.917^{\circ}$ deviation (Table S4).

The $\mathrm{N} 1 \bullet \bullet \bullet \mathrm{N} 2, \mathrm{~N} 1 \bullet \bullet \bullet \mathrm{O} 2$, and $\mathrm{N} 2 \bullet \bullet \bullet \mathrm{O} 2$ distances in the free ligand $(3.788,4.261$, and $7.003 \AA$ ) are longer than those in the metal complex $(2.777,2.717$, and $2.950 \AA$ ) due to metal complex formation through N1, N2, and O2.

The natural charges on the coordinated atoms derived by NBO analysis are $\mathrm{Ni}(+0.779)$, $\mathrm{O} 2(-0.655), \mathrm{N} 1(-0.541), \mathrm{N} 2(-0.700), \mathrm{N} 3(-0.528), \mathrm{O} 4(-0.747)$, and O3 $(-0.905)$.

\subsection{4. $\left[\mathrm{Cd}(\mathrm{S})(\mathrm{Q})\left(\mathrm{H}_{2} \mathrm{O}\right)\right]$}

Figure $9 \mathrm{C}$ shows the optimized structures of the metal complex $\left[\mathrm{Cd}(\mathrm{S})(\mathrm{Q})\left(\mathrm{H}_{2} \mathrm{O}\right)\right]$ as the lowest-energy configurations. The $\mathrm{Cd}$ atom is six-coordinate in octahedral geometry with $\mathrm{N} 1, \mathrm{~N} 2, \mathrm{Cl}$, and $\mathrm{O} 2$, being almost coplanar, deviating by $-7.655^{\circ}$ (Table S5).

The $\mathrm{N} 1 \bullet \bullet \bullet \mathrm{N} 2, \mathrm{~N} 1 \bullet \bullet \bullet \mathrm{O} 2$, and $\mathrm{N} 2 \bullet \bullet \bullet \mathrm{O} 2$ distances in the free ligand $(3.788,4.261$, and $7.003 \AA$ ) are longer than those in the metal complex $(2.886,2.874$, and $3.349 \AA$ ) due to metal complex formation through $\mathrm{N} 1, \mathrm{~N} 2$, and $\mathrm{O} 2$.

The natural charges on the coordinated atoms derived by $\mathrm{NBO}$ analysis are $\mathrm{Cd}(+1.474)$, $\mathrm{O} 2(-0.843), \mathrm{N} 1(-0.672), \mathrm{N} 2(-0.750), \mathrm{N} 3(-0.616), \mathrm{O} 4(-0.841)$, and O3 $(-0.987)$. 


\subsection{5. $\left[\mathrm{Al}(\mathrm{S})(\mathrm{Q})\left(\mathrm{H}_{2} \mathrm{O}\right)\right]^{+}$}

Figure 9D shows the optimized structures of the metal complex $\left[\mathrm{Al}(\mathrm{S})(\mathrm{Q})\left(\mathrm{H}_{2} \mathrm{O}\right)\right]^{+}$as the lowest-energy configurations. The $\mathrm{Al}$ atom is six-coordinate in octahedral geometry, with N1, N2, N3, and O4 being almost coplanar, deviating by $-5.790^{\circ}$ (Table S6).

The $\mathrm{N} 1 \bullet \bullet \bullet \mathrm{N} 2, \mathrm{~N} 1 \bullet \bullet \bullet \mathrm{O} 2$, and $\mathrm{N} 2 \bullet \bullet \bullet \mathrm{O} 2$ distances in the free ligand $(3.788,4.261$, and $7.003 \AA$ ) are longer than those in the metal complex $(2.674,2.673$, and $2.872 \AA)$ due to metal complex formation through N1, N2, and O2.

The natural charges on the coordinated atoms according to $\mathrm{NBO}$ analysis are $\mathrm{Al}$ $(+2.116), \mathrm{O} 2(-0.916), \mathrm{N} 1(-0.763), \mathrm{N} 2(-0.858), \mathrm{N} 3(-0.695), \mathrm{O} 4(-0.920)$, and O3 $(-1.006)$.
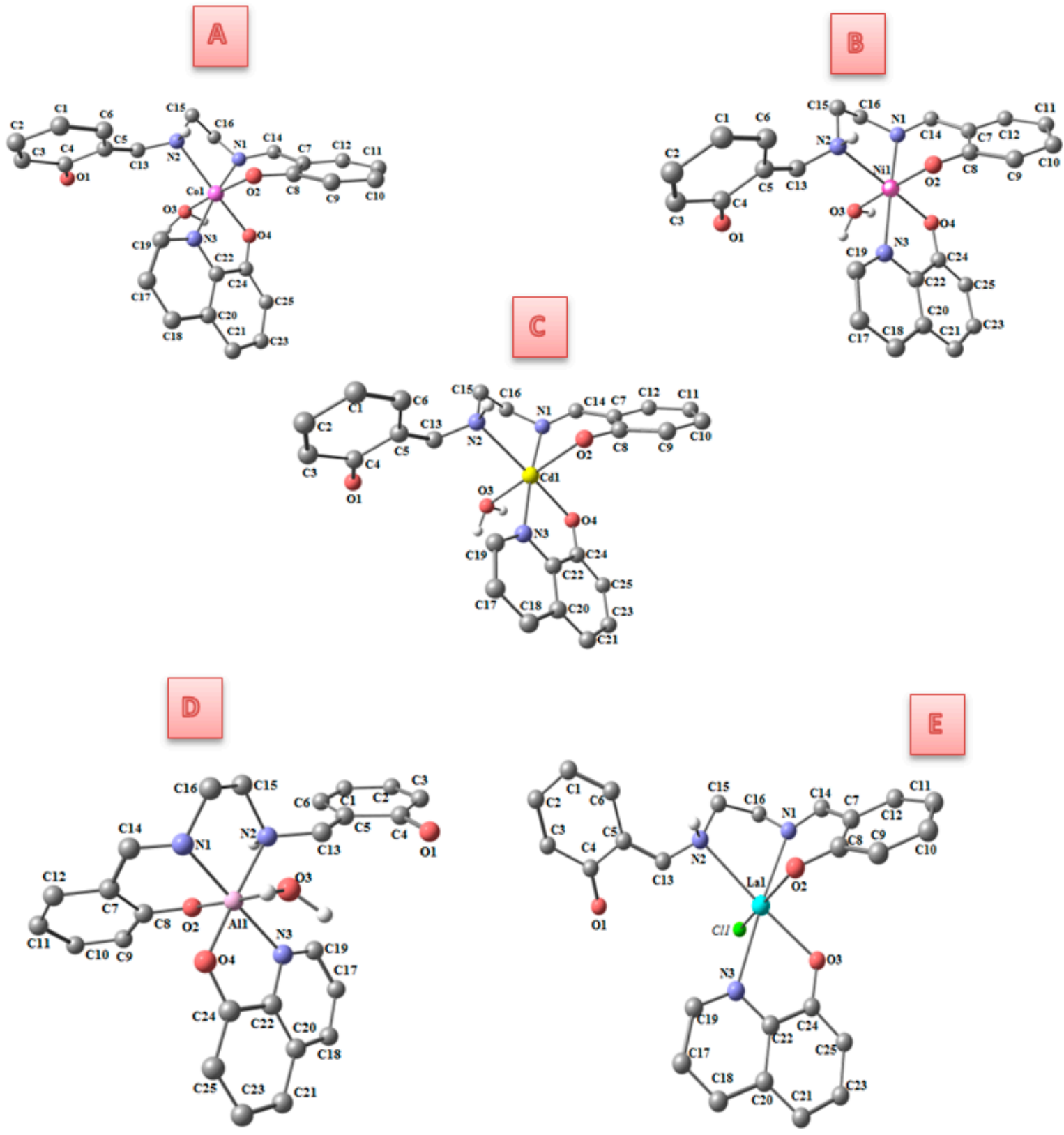

Figure 9. The optimized structure of $\left[\mathrm{Co}(\mathrm{S})(\mathrm{Q})\left(\mathrm{H}_{2} \mathrm{O}\right)\right](\mathbf{A}),\left[\mathrm{Ni}(\mathrm{S})(\mathrm{Q})\left(\mathrm{H}_{2} \mathrm{O}\right)\right](\mathbf{B}),\left[\mathrm{Cd}(\mathrm{S})(\mathrm{Q})\left(\mathrm{H}_{2} \mathrm{O}\right)\right](\mathbf{C}),\left[\mathrm{Al}(\mathrm{S})(\mathrm{Q})\left(\mathrm{H}_{2} \mathrm{O}\right)\right]^{+}(\mathbf{D})$, and $[\mathrm{La}(\mathrm{S})(\mathrm{Q}) \mathrm{Cl}](\mathbf{E})$ using B3LYP/LANL2DZ. H atoms on carbon atoms are omitted for clarity. 
Table 6. Selected bond distances in $\AA$ and angles in ${ }^{\circ}$ of the metal metal complexes.

\begin{tabular}{|c|c|c|c|c|c|c|c|}
\hline Bond & Length (Å) & Bond & Angle $\left(^{\circ}\right)$ & Bond & Length (Å) & Bond & Angle $\left({ }^{\circ}\right)$ \\
\hline Metal & & & & Metal & & & \\
\hline Complex 1 & & & & Complex 2 & & & \\
\hline $\operatorname{CoSQ}$ & & & & NiSQ & & & \\
\hline Co-N1 & 1.908 & N1-Co-N2 & 80.28 & $\mathrm{Ni}-\mathrm{N} 1$ & 2.151 & $\mathrm{~N} 1-\mathrm{Ni}-\mathrm{N} 2$ & 78.22 \\
\hline $\mathrm{Co}-\mathrm{N} 2$ & 2.272 & N3-Co-O4 & 82.38 & $\mathrm{Ni}-\mathrm{N} 2$ & 2.249 & N3-Ni-O4 & 78.98 \\
\hline $\mathrm{Co}-\mathrm{N} 3$ & 1.993 & $\mathrm{~N} 1-\mathrm{Co}-\mathrm{O} 4$ & 91.04 & $\mathrm{Ni}-\mathrm{N} 3$ & 2.288 & $\mathrm{~N} 1-\mathrm{Ni}-\mathrm{O} 4$ & 100.1 \\
\hline $\mathrm{Co}-\mathrm{O} 4$ & 2.113 & N2-Co-N3 & 106.6 & $\mathrm{Ni}-\mathrm{O} 4$ & 2.071 & $\mathrm{~N} 2-\mathrm{Ni}-\mathrm{N} 3$ & 102.8 \\
\hline $\mathrm{Co}-\mathrm{O} 2$ & 2.007 & $\mathrm{O} 2-\mathrm{Co}-\mathrm{N} 1$ & 88.00 & $\mathrm{Ni}-\mathrm{O} 2$ & 1.860 & $\mathrm{O} 2-\mathrm{Ni}-\mathrm{N} 1$ & 84.96 \\
\hline \multirow[t]{15}{*}{$\mathrm{Co}-\mathrm{O} 3$} & 2.162 & $\mathrm{O} 2-\mathrm{Co}-\mathrm{N} 2$ & 90.52 & $\mathrm{Ni}-\mathrm{O} 3$ & 1.997 & $\mathrm{O} 2-\mathrm{Ni}-\mathrm{N} 2$ & 91.27 \\
\hline & & $\mathrm{O} 2-\mathrm{Co}-\mathrm{N} 3$ & 89.90 & & & $\mathrm{O} 2-\mathrm{Ni}-\mathrm{N} 3$ & 93.69 \\
\hline & & $\mathrm{O} 2-\mathrm{Co}-\mathrm{O} 4$ & 96.57 & & & $\mathrm{O} 2-\mathrm{Ni}-\mathrm{O} 4$ & 92.46 \\
\hline & & Bond & Length (̊̊) & Bond & Angle $\left({ }^{\circ}\right)$ & & \\
\hline & & Metal & & & & & \\
\hline & & Complex 3 & & & & & \\
\hline & & CdSQ & & & & & \\
\hline & & $\mathrm{Cd}-\mathrm{N} 1$ & 2.227 & $\mathrm{~N} 1-\mathrm{Cd}-\mathrm{N} 2$ & 76.87 & & \\
\hline & & $\mathrm{Cd}-\mathrm{N} 2$ & 2.409 & N3-Cd-O4 & 77.40 & & \\
\hline & & $\mathrm{Cd}-\mathrm{N} 3$ & 2.312 & $\mathrm{~N} 1-\mathrm{Cd}-\mathrm{O} 4$ & 99.93 & & \\
\hline & & $\mathrm{Cd}-\mathrm{O} 4$ & 2.219 & $\mathrm{~N} 2-\mathrm{Cd}-\mathrm{N} 3$ & 106.2 & & \\
\hline & & $\mathrm{Cd}-\mathrm{O} 2$ & 2.231 & $\mathrm{O} 2-\mathrm{Cd}-\mathrm{N} 1$ & 80.28 & & \\
\hline & & $\mathrm{Cd}-\mathrm{O} 3$ & 2.372 & $\mathrm{O} 2-\mathrm{Cd}-\mathrm{N} 2$ & 92.34 & & \\
\hline & & & & $\mathrm{O} 2-\mathrm{Cd}-\mathrm{N} 3$ & 95.24 & & \\
\hline & & & & $\mathrm{O} 2-\mathrm{Cd}-\mathrm{O} 4$ & 92.80 & & \\
\hline Bond & Length (Å) & Bond & Angle ( $\left.{ }^{\circ}\right)$ & Bond & Length (Å) & Bond & Angle $\left(^{\circ}\right)$ \\
\hline Metal & & & & Metal & & & \\
\hline Complex 4 & & & & Complex 5 & & & \\
\hline AlSQ & & & & LaSQ & & & \\
\hline $\mathrm{Al}-\mathrm{N} 1$ & 1.974 & N1-Al-N2 & 81.42 & La-N1 & 2.534 & N1-La-N2 & 69.55 \\
\hline $\mathrm{Al}-\mathrm{N} 2$ & 2.122 & N3-Al-O4 & 83.86 & La-N2 & 2.704 & N3-La-O3 & 69.70 \\
\hline $\mathrm{Al}-\mathrm{N} 3$ & 2.065 & $\mathrm{~N} 1-\mathrm{Al}-\mathrm{O} 4$ & 95.59 & $\mathrm{La}-\mathrm{O} 3$ & 2.402 & N1-La-O3 & 107.2 \\
\hline $\mathrm{Al}-\mathrm{O} 4$ & 1.891 & $\mathrm{~N} 2-\mathrm{Al}-\mathrm{N} 3$ & -104.9 & La-N3 & 2.621 & N2-La-N3 & 113.5 \\
\hline $\mathrm{Al}-\mathrm{O} 2$ & 1.869 & $\mathrm{O} 2-\mathrm{Al}-\mathrm{N} 1$ & 88.13 & $\mathrm{La}-\mathrm{Cl}$ & 2.828 & O2-La-N1 & 75.55 \\
\hline \multirow[t]{3}{*}{$\mathrm{Al}-\mathrm{O} 3$} & 2.052 & $\mathrm{O} 2-\mathrm{Al}-\mathrm{N} 2$ & 92.34 & $\mathrm{La}-\mathrm{O} 2$ & 2.396 & $\mathrm{O} 2-\mathrm{La}-\mathrm{N} 2$ & 91.96 \\
\hline & & $\mathrm{O} 2-\mathrm{Al}-\mathrm{N} 3$ & 91.84 & & & $\mathrm{O} 2-\mathrm{La}-\mathrm{N} 3$ & 97.13 \\
\hline & & $\mathrm{O} 2-\mathrm{Al}-\mathrm{O} 4$ & 97.74 & & & $\mathrm{O} 2-\mathrm{La}-\mathrm{O} 3$ & 87.36 \\
\hline
\end{tabular}

\subsection{6. $[\mathrm{La}(\mathrm{S})(\mathrm{Q}) \mathrm{Cl}] \mathrm{H}_{2} \mathrm{O}$}

Figure $9 \mathrm{E}$ shows the optimized structures of the metal complex $[\mathrm{La}(\mathrm{S})(\mathrm{Q}) \mathrm{Cl}] \mathrm{H}_{2} \mathrm{O}$ as the lowest-energy configurations. The La atom is six-coordinate in octahedral geometry with N1, N2, N3, and O3 being almost coplanar, deviating by $-5.859^{\circ}$ (Table S7).

The $\mathrm{N} 1 \bullet \bullet \bullet \mathrm{N} 2, \mathrm{~N} 1 \bullet \bullet \bullet \mathrm{O} 2$, and $\mathrm{N} 2 \bullet \bullet \bullet \mathrm{O} 2$ distances in the free ligand $(3.788,4.261$, and $7.003 \AA$ ) are longer than those in the metal complex $(2.991,3.022$, and $3.674 \AA$ ) due to metal complex formation through $\mathrm{N} 1, \mathrm{~N} 2$, and $\mathrm{O} 2$.

The natural charges on the coordinated atoms derived by NBO analysis are $\mathrm{La}(+1.247)$, $\mathrm{O} 2(-0.572), \mathrm{N} 1(-0.277), \mathrm{N} 2(-0.567), \mathrm{N} 3(-0.289), \mathrm{O} 3(-0.572)$, and $\mathrm{Cl}(-0.460)$.

Figure $\mathrm{S} 6$ shows the molecular electrostatic potential (MEP) surface, identifying the positively (blue) and negatively (red, loosely bound, or excess electrons) charged electrostatic potentials in the molecule. The computed total energy, the highest occupied molecular orbital (HOMO) energies, the lowest unoccupied molecular orbital (LUMO) energies, and the dipole moments for the ligands and metal complexes were calculated and are displayed in Table 7 and Figure S7. The more negative values of total energy for the metal complexes than those of the free ligands indicate that the metal complexes are 
more stable than the free ligands. Furthermore, the energy gaps (Eg = ELUMO - EHOMO) were found to be smaller in the metal complexes than that of the ligand due to chelation of the ligand to the metal ions. The lower Eg in the metal complexes compared to that of the ligand explains the charge-transfer interactions upon metal complex formation.

Table 7. Calculated energies for Schiff bases and their complexes at B3LYP/6-311++g(d,p) for all atoms and at B3LYP/LANL2DZ level of theory for metal ions.

\begin{tabular}{cccccc}
\hline Compounds & $\mathbf{E}^{\mathbf{a}}$ & HOMO $^{\mathbf{b}}$ & LUMO $^{\mathbf{c}}$ & $\mathbf{E}_{\mathbf{g}} \mathbf{d}^{\mathbf{2}}$ & Dipole Moment $^{\mathbf{e}}$ \\
\hline $\mathrm{L}($ Keto-Enol$)$ & -879.513 & -5.6271 & -2.0787 & 3.5484 & 4.3162 \\
{$\left[\mathrm{Co}(\mathrm{S})(\mathrm{Q})\left(\mathrm{H}_{2} \mathrm{O}\right)\right]$} & -1576.606 & -4.7207 & -2.8774 & 1.8433 & 4.0495 \\
{$\left[\mathrm{Ni}(\mathrm{S})(\mathrm{Q})\left(\mathrm{H}_{2} \mathrm{O}\right)\right]$} & -1600.769 & -4.5141 & -2.8635 & 1.6506 & 4.6864 \\
{$\left[\mathrm{Cd}(\mathrm{S})(\mathrm{Q})\left(\mathrm{H}_{2} \mathrm{O}\right)\right]$} & -1479.550 & -4.7561 & -3.1797 & 1.5764 & 6.0024 \\
{$\left[\mathrm{Al}(\mathrm{S})(\mathrm{Q}) \mathrm{H}_{2} \mathrm{O}\right]^{+}$} & -1433.425 & -8.3346 & -6.0168 & 2.3178 & 3.9957 \\
{$[\mathrm{La}(\mathrm{S})(\mathrm{Q}) \mathrm{Cl}] \mathrm{H}_{2} \mathrm{O}$} & -1401.433 & -5.1707 & -3.7108 & 1.4599 & 11.4398 \\
\hline
\end{tabular}

${ }^{a}$ E: the total energy (Hartree). ${ }^{\mathrm{b}}$ HOMO: highest occupied molecular orbital (eV). ${ }^{\mathrm{c}}$ LUMO: lowest unoccupied molecular orbital (eV).

${ }^{\mathrm{d}} \mathrm{E}_{\mathrm{g}}=\mathrm{E}_{\mathrm{LUMO}}-\mathrm{E}_{\mathrm{HOMO}}(\mathrm{eV}) .{ }^{\mathrm{e}}$ dipole moment (Debye).

\subsection{Antimicrobial Bioassay}

A much greater number of drugs are active against Gram-positive than Gram-negative bacteria [47]. In this study, the titled compounds are active against both types of bacteria, which may indicate broad-spectrum antibacterial properties.

The synthesized salen ligand and its mixed 8-hydroxyquinoline metal complexes of $\mathrm{Co}(\mathrm{II}), \mathrm{Ni}(\mathrm{II}), \mathrm{Cd}(\mathrm{II}), \mathrm{Al}(\mathrm{III})$, and $\mathrm{La}(\mathrm{III})$ were screened for their antibacterial activities against E. coli and P. virgules (Gram-negative bacteria), and S. aureus and B. subtilis (Grampositive bacteria), as well as for antifungal activities against $C$. albicans and $A$. favas. The agar diffusion technique was used to evaluate the antibacterial activities of the investigated compounds. The biological activities of the salen ligand, metal salt: $\left(\mathrm{CoCl}_{2} 6 \mathrm{H}_{2} \mathrm{O}\right),\left(\mathrm{NiCl}_{2} 6 \mathrm{H}_{2} \mathrm{O}\right)$, $\left(\mathrm{CdCl}_{2} \mathrm{H}_{2} \mathrm{O}\right),\left(\mathrm{AlCl}_{3} 6 \mathrm{H}_{2} \mathrm{O}\right)$, and $\left(\mathrm{LaCl}_{3} 7 \mathrm{H}_{2} \mathrm{O}\right)$, and its mixed 8-hydroxyquinoline metal complexes were compared with those of the standard drugs gentamicin as an antibiotic and ketoconazole as antifungal agent.

The results are listed in Tables S1 and S2 and Figure 10A-C. These data show that mixed salen metal complexes were more potent in inhibiting the growth of microorganisms than the salen ligand. $\mathrm{Cd}(\mathrm{II})$-salen/8-hydroxyquinoline metal complex had a stronger antibacterial efficacy against all bacterial strains except Escherichia coli (-ve); its inhibition zone was larger than that of the reference drug gentamicin. The inhibition potencies of mixed ligand metal complexes follow the order: AlSQ $>$ LaSQ $>$ CdSQ $>$ gentamycin $>$ $\mathrm{NiSQ}>\mathrm{CoSQ}>\mathrm{Q}>\mathrm{S}$, LaSQ $>\mathrm{CdSQ}>$ gentamycin $>\mathrm{AlSQ}>\mathrm{NiSQ}>\mathrm{CoSQ}>\mathrm{Q}>\mathrm{S}$, gentamycin $>\mathrm{CdSQ}>\mathrm{AlSQ}>\mathrm{LaSQ}>\mathrm{NiSQ}>\mathrm{CoSQ}>\mathrm{Q}>\mathrm{S}$ and CdSQ $>$ LaSQ $>$ gentamycin $>$ AlSQ $>$ NiSQ $>\mathrm{Q}>\mathrm{S}>\mathrm{CoSQ}$ against P. vulgaris (-ve), E. coli (-ve), B. subtilis (+ve), and $S$. aureus (+ve). The antifungal activity of the mixed salen/8-hydroxyquinoline metal complexes were tested against $C$. albicans and A. flavus. The obtained results revealed that all the compounds inhibited the growth of the studied fungi except CoSQ and NiSQ, which had no antifungal activity. Differences in cell wall structure can lead to differences in antibacterial susceptibility, with some antibiotics able to kill only Gram-positive pathogens [47]. For example, Gram-positive bacteria possess a thick cell wall containing many layers of peptidoglycan and teichoic acids, while Gram-negative bacteria have relatively thin cell walls consisting of a few layers of peptidoglycan surrounded by a second lipid membrane containing lipopolysaccharides and lipoproteins. 

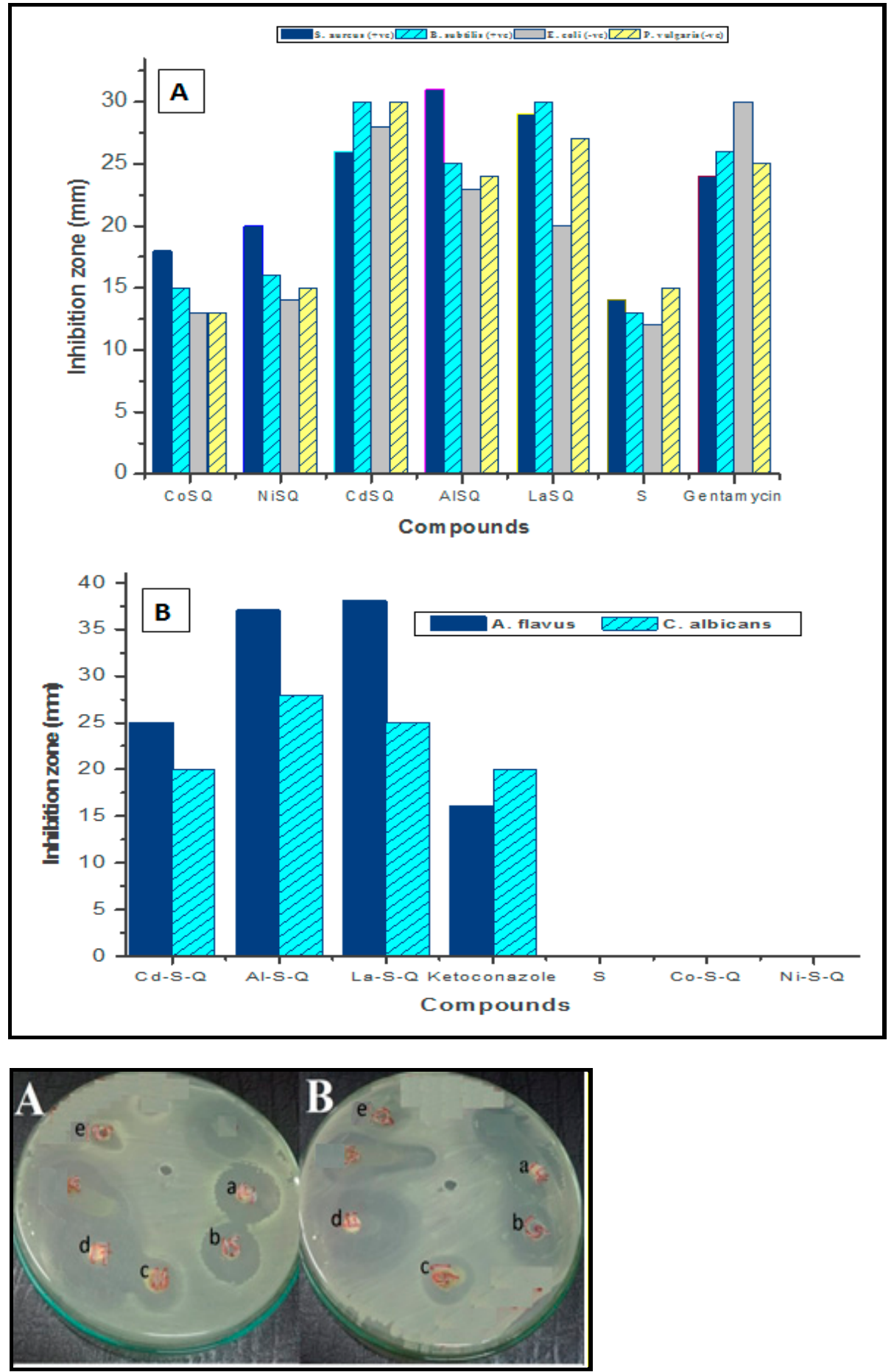

(C)

Figure 10. Graph showing the comparative (A) antibacterial activity of MSQ metal complexes against gentamycin as reference drug and (B) antifungal bioassay of MSQ metal complexes against ketoconazole at concentration of $10 \mathrm{mg} \mathrm{mL}^{-1}$ as reference drug. (C) Inhibition zone of MSQ metal complexes against (A) Gram-positive bacteria B. subtilis (+ve) and (B) Gram-negative bacteria P. vulgaris (-ve). (a) LaSQ, (b) AlSQ, (c) NiSQ, (d) CdSQ, (e) S at $10 \mathrm{mg} / \mathrm{mL}$.

The variation in the activities of metal complexes against different organisms depends on the impermeability of the microorganism cells or on differences in their ribosomes [48]. Furthermore, the size of the inhibition zone depends upon the concentration of the antibacterial agent where other factors such as culture medium, incubation conditions, and rate of 
diffusion have been fixed. The activities of all the tested metal complexes may be explained in terms of chelation theory because the free ligand and metal ion have less antimicrobial activity, while at their connection to form metal complex the activity increased $[49,50]$; moreover, chelation reduces the polarity of the metal atom, mainly because of partial sharing of its positive charge with the donor groups and possible p-electron delocalization over the chelate ring. Furthermore, chelation increases the lipophilic nature of the central atom, which favors its permeation through the lipid layer of cell membranes [51]. The importance of these results lies in the fact that these metal complexes could be applied in the treatment of some common diseases caused by E. coli, e.g., septicemia, gastroenteritis, urinary tract infections, and hospital-acquired infections [52]. The noted enhancement in the activity of MSQ compared to their MS binary metal complexes as well as the conceptually and structurally related mixed salen/imidazole metal complexes (MSI) [44] being directly related to introducing 8-hydroxyquinoline $(\mathrm{Q})$ moiety as a secondary ligand. Moreover, probing the antimicrobial activity of the prepared MSQ metal complexes along with their mechanisms of action revealed that the high lipophilicity of $Q$ facilitates the penetration of bacterial cell membranes to reach its target site of action. This most likely to be a metal-binding site of bacterial enzymes. In this respect, the MSQ metal complexes is assumed to undergo a dissociation reaction to liberate a positively charged MS species and free $Q$ ligand [29]. Then, the charged MS species may bind and block the metal-binding sites on bacterial enzymes, thereby inducing the antimicrobial effect [31]. Thus, the lipophilicity is considered to be a crucial factor for antimicrobial activity of the investigated MSQ metal complexes. Moreover, the dissociated free $Q$ ligand has high chelating affinity that enabled its binding to the metallic prosthetic groups of microbial enzymes, thus leading to inhibition of enzymatic activity.

\subsection{Cytotoxicity}

The in vitro cytotoxicity of the mixed metal complexes against human liver carcinoma Hep-G2 cells and breast carcinoma cell line MDA-MB 231 were determined using MTT assay, in which mitochondrial dehydrogenase activity was measured as an indication of cell viability. The absorbance values were analyzed by non-linear regression to obtain $\mathrm{IC}_{50}$ values for the five different metal complexes against both cancer cell lines.

The cytotoxicity study of the salen ligand and its mixed 8-hydroxyquinoline metal complexes of $\mathrm{Co}(\mathrm{II}), \mathrm{Ni}(\mathrm{II}), \mathrm{Cd}(\mathrm{II}), \mathrm{Al}(\mathrm{III})$, and $\mathrm{La}(\mathrm{III})$ against HepG-2 and MDA-MB 231 at concentrations of $0,0.1,1,10$, and $100 \mu \mathrm{M}$ are shown in (Figure S8). On the basis of the results of the surviving fraction of the different compounds and their $\mathrm{IC}_{50}$ values, we have displayed the activity of salen and its metal complexes in Table 8.

Table 8. $\mathrm{IC}_{50}$ values in $\mu \mathrm{M}$ for the salen ligand and its mixed 8-hydroxyquinoline metal complexes against Hep-G2 and MDA-MB231 cell lines compared to cisplatin.

\begin{tabular}{cccc}
\hline \multirow{2}{*}{ Compounds } & \multicolumn{3}{c}{ IC $_{\mathbf{5 0}}$ Values $\boldsymbol{\mu M}$} \\
\cline { 2 - 4 } & Hep-G2 Cell Line & MDA-MB231 Cell Line & HEK-293 Cell Lines \\
\hline Cisplatin & $1.55 \pm 0.06$ & $1.87 \pm 0.09$ & $94.10 \pm 0.05$ \\
S & $1.10 \pm 0.10$ & $27.54 \pm 0.08$ & $93.06 \pm 0.04$ \\
CoSQ & $1.49 \pm 0.09$ & $109.64 \pm 0.11$ & $91.80 \pm 0.07$ \\
NiSQ & $67.6 \pm 0.04$ & $102.32 \pm 0.07$ & $93.05 \pm 0.05$ \\
CdSQ & $6.19 \pm 0.08$ & $1.95 \pm 0.10$ & $91.88 \pm 0.08$ \\
AlSQ & $5.72 \pm 0.13$ & $2.66 \pm 0.05$ & $91.90 \pm 0.05$ \\
LaSQ & $1.95 \pm 0.06$ & $1.43 \pm 0.12$ & $93.03 \pm 0.10$ \\
\hline
\end{tabular}

Figure $11 \mathrm{~A}$ shows the $\mathrm{IC}_{50}$ values of salen and its mixed metal complexes with 8-hydroxyquinoline against the HepG-2 cancer cell line. From these data, we can conclude that salen $\left(\mathrm{IC}_{50}=1.1 \mu \mathrm{M}\right)$ and its CoSQ metal complex $\left(\mathrm{IC}_{50}=1.49 \mu \mathrm{M}\right)$ have the greatest activities against the HepG-2 cancer cell line. The $\mathrm{IC}_{50}$ values of salen and its Co metal complex are lower than that of the standard drug cisplatin $(1.55 \mu \mathrm{M})$. The $\mathrm{IC}_{50}$ values of 
the metal complexes CdSQ, AISQ, and LaSQ were found to be 6.19, 5.72, and $1.95 \mu \mathrm{M}$, respectively, which were of the same order of magnitude as the reference drug cisplatin $(1.55 \mu \mathrm{M})$.

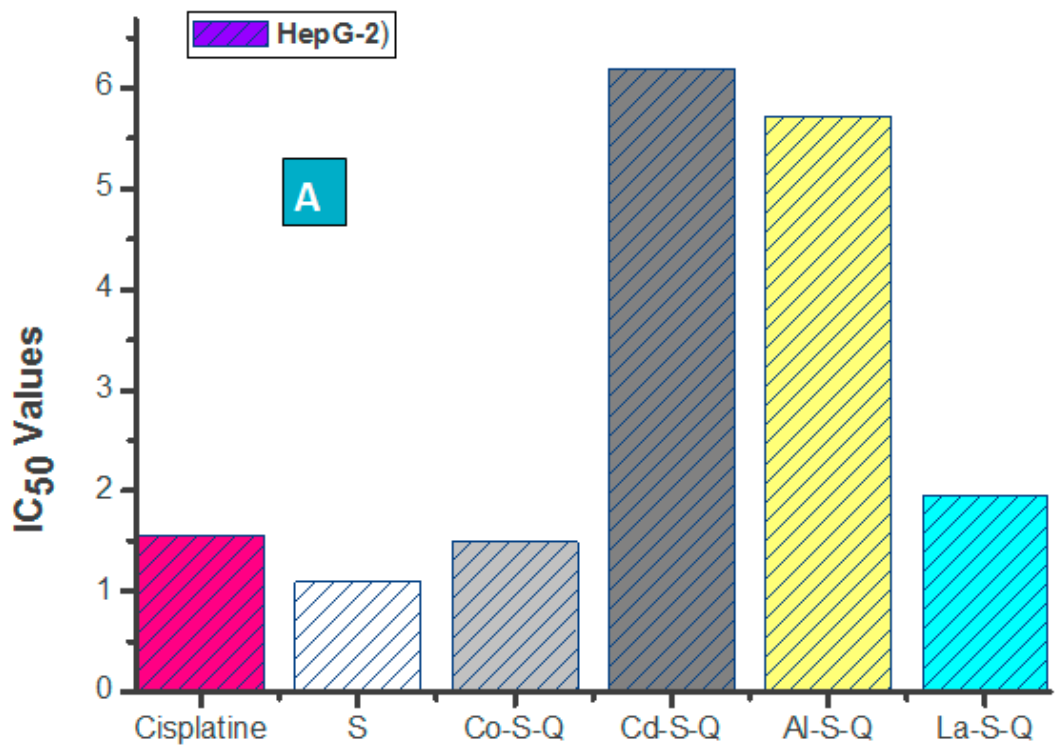

Compounds

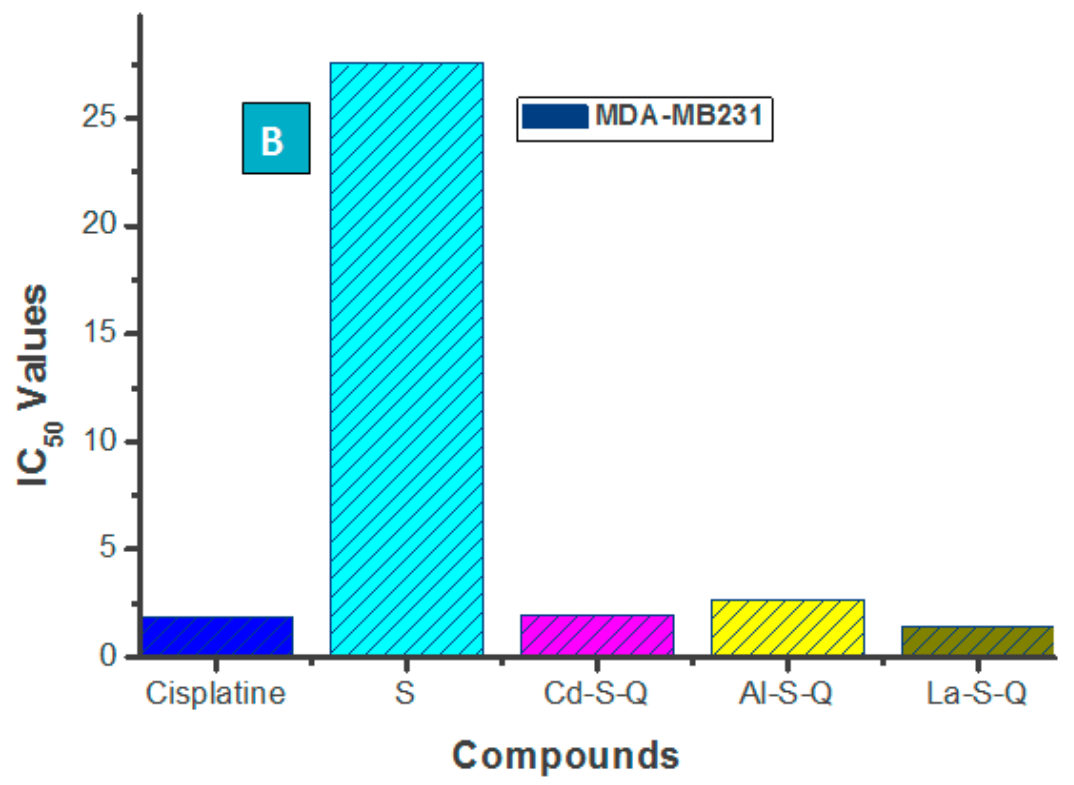

Figure 11. $\mathrm{IC}_{50}$ Values of salen and its $\mathrm{Cd}(\mathrm{II}), \mathrm{Al}(\mathrm{III})$, and $\mathrm{La}(\mathrm{III})$ mixed 8-hydroxyquinoline metal complexes against (A) Hep-G2 carcinoma cell lines compared to cisplatin and against MDA-MB231 (B) breast carcinoma cell lines compared to cisplatin.

Figure 11B shows the cytotoxicity of salen and its mixed 8-hydroxyquinoline metal complexes against the breast cancer carcinoma cell line MDA-MB 231. The $\mathrm{IC}_{50}$ values of the metal complexes CdSQ $(1.95 \mu \mathrm{M})$, AlSQ $(2.66 \mu \mathrm{M})$, and LaSQ $(1.43 \mu \mathrm{M})$ were lower than that of salen $(27.54 \mu \mathrm{M})$. This means that the Cd(II) metal complexes [53-55] exhibited the highest activity against breast cancer cell line MDA-MB231. The $\mathrm{IC}_{50}$ values followed the order LaSQ $<$ cisplatin $<$ CdSQ $<$ AlSQ $<$ salen.

From the obtained results, we are able to see that the new mixed ligand compounds are potent drugs against human liver carcinoma cell line HepG-2 and breast cancer carcinoma cell line MDA-MB 231, especially the metal complexes CoSQ and LaSQ, which are 
more potent than the reference drug cisplatin and show concentration-dependent effects, indicating the potential of these metal complexes in cancer therapy. More importantly, the prepared metal complexes are highly specific towards cancer cell lines only, as they exhibited mild toxicity against normal cell line (HEK-293), as illustrated in Table 8 and Figure S9.

\subsection{Molecular Docking Studies}

Molecular docking studies were performed using MOA2014 software [32] in order to explore the possible binding modes for the most active site of the receptor of breast cancer oxidoreductase (PDB ID: 3HB5). The crystal structures of the 3HB5 breast cancer receptor were downloaded from the Protein Data Bank (http:/ / www.rcsb.org./pdb accessed date 21 April 2021). The structures of salen and its metal complexes were created in PDB file format using the Gaussian09 software package.

The binding affinities of the ligand and the synthesized CdSQ metal complexes against the receptor of 3HB5 are shown in Figures 12 and 13 and Table 9. The binding energies of the ligand and its metal complexes with the target protein receptor follow the order CdSQ $>$ salen, which agrees with the experimental results.

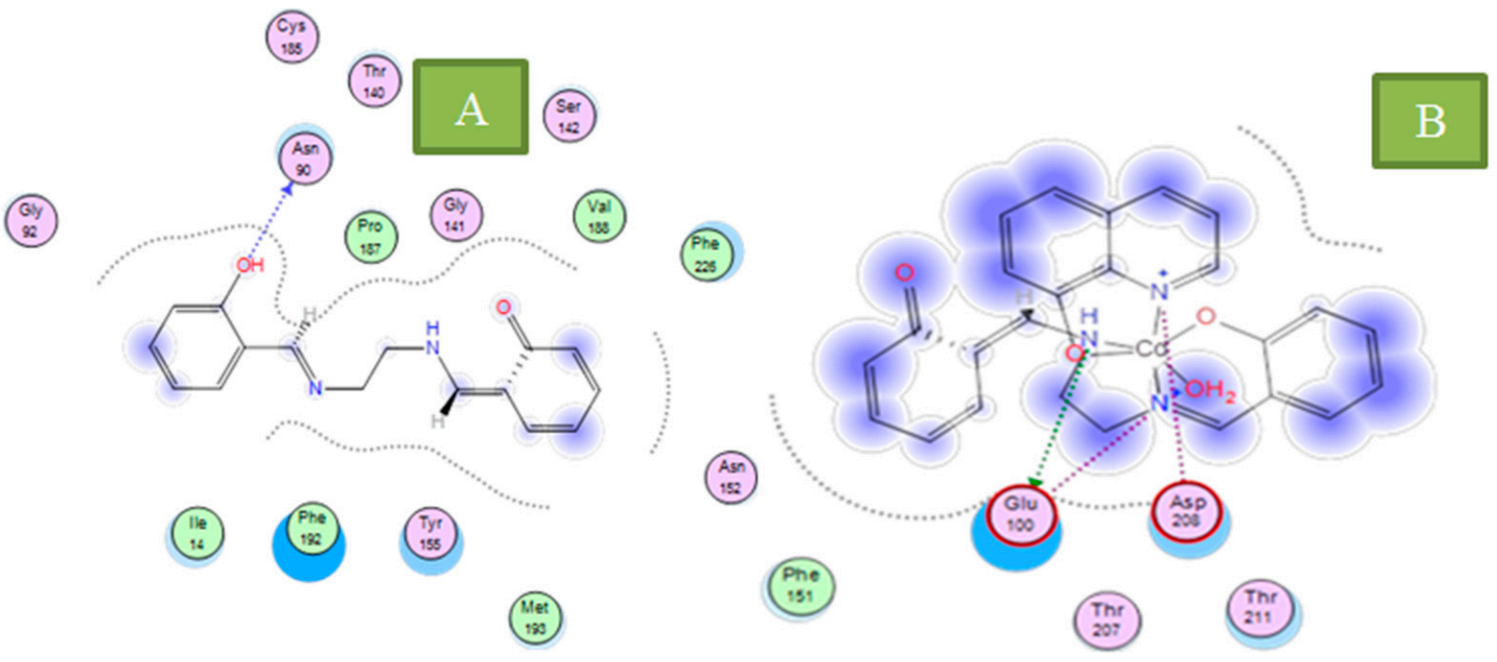

Figure 12. 2D plot of the interaction between the ligand (A) and Cd(II) metal complex (B) with the active site of the receptor of breast cancer oxidoreductase (PDB ID: 3HB5). Hydrophobic interactions with amino acid residues are shown with dotted curves.

Table 9. Docking interaction data for the ligand $\left[\mathrm{Cd}(\mathrm{S})(\mathrm{Q})\left(\mathrm{H}_{2} \mathrm{O}\right)\right]$ with the active site of the receptor of breast cancer oxidoreductase (PDB ID: 3HB5).

\begin{tabular}{ccccc}
\hline Compounds & Receptor & Interaction & Distance (Å) & E (Kcal/mol) \\
\hline Ligand & O ASN 90 & H-donor & $3.03(2.06)$ & -3.1 \\
O 16 & & & \\
Cd(II) metal complex & OE1 GLU 100 & H-donor & $3.04(2.02)$ & -13.3 \\
N 18 & OE1 GLU 100 & Ionic & 3.68 & -1.3 \\
N 17 & OE2 GLU 100 & Ionic & 3.85 & -0.8 \\
N 17 & OE1 GLU 100 & Ionic & 3.04 & -4.2 \\
N 18 & OE2 GLU 100 & Ionic & 3.48 & -2.0 \\
N 18 & OD1 ASP 208 & Ionic & 3.41 & -2.3 \\
N 44 & &
\end{tabular}

* The lengths of H-bonds are in brackets. 

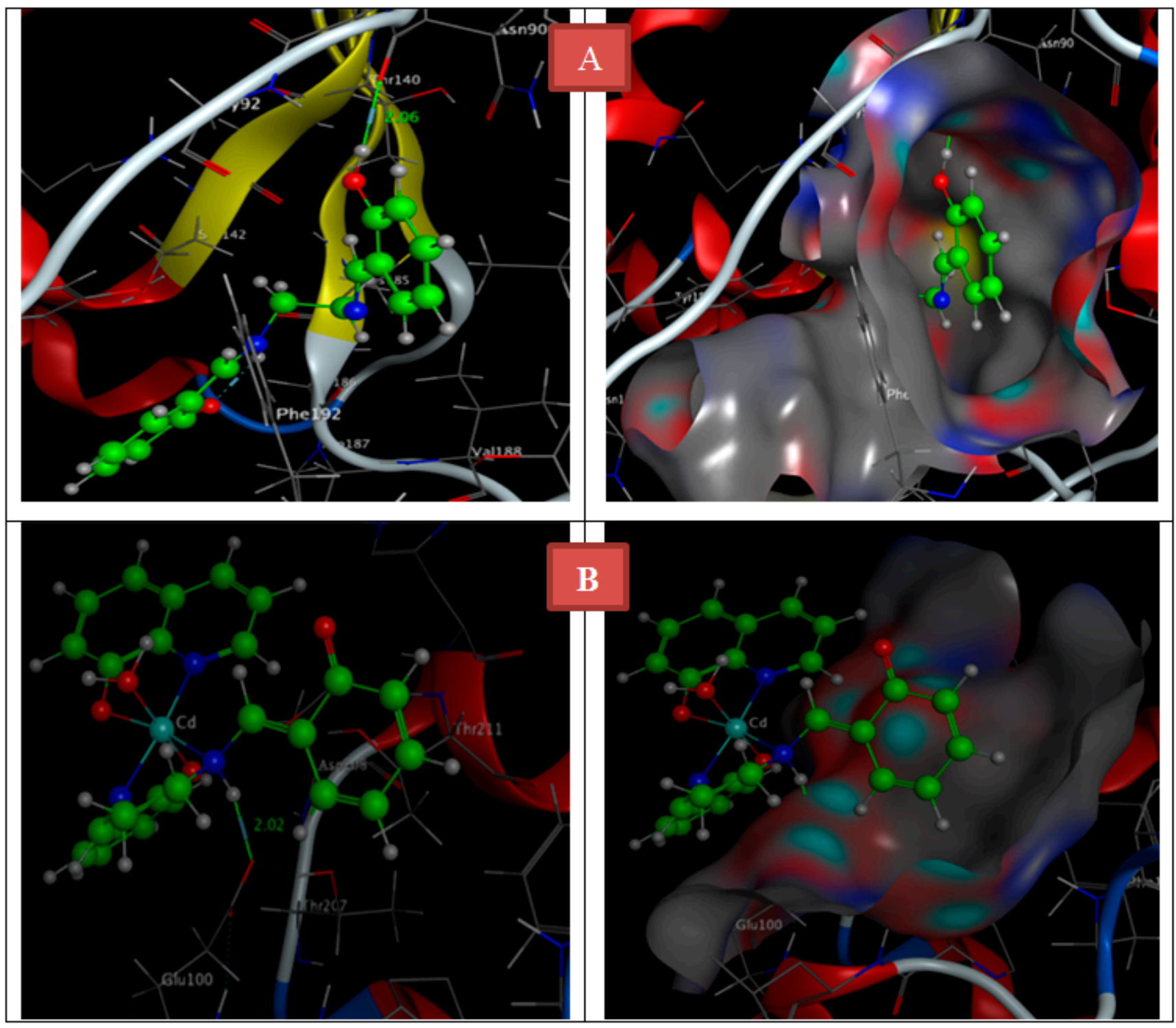

Figure 13. Molecular docking simulation studies of the interaction between the ligand (A) and Cd(II) metal complex (B), with the active site of the receptor of breast cancer oxidoreductase (PDB ID: 3HB5). The docked conformation of the compound is shown in ball and stick representation.

\section{Conclusions}

In the current work, we studied the anti-cancer and anti-microbial effect of Co(II), $\mathrm{Ni}(\mathrm{II}), \mathrm{Cd}(\mathrm{II}), \mathrm{Al}(\mathrm{III})$, and La(III) metal complexes of mixed ligand(2,2' $-\{1,2$-ethanediylbis [nitrilo(E) methylylidene]\}diphenol with 8-hydroxy quinolone. The quantum calculation, analytical, and experimental measurements seem to suggest the proposed structure of the compounds. Molecular docking studies were performed to investigate the binding of the synthesized compounds with breast cancer oxidoreductase (PDB ID: 3HB5). The outcomes can be abbreviated as follows:

1. The metal complexes exhibited high cytotoxic potency against human breast cancer (MDA-MB231) and liver cancer (Hep-G2) cell lines.

2. The anticancer results showed that the $\mathrm{IC}_{50}$ values of CoSQ and LaSQ were 1.49 and $1.95 \mu \mathrm{M}$, respectively, which is comparable to that of cisplatin $(1.55 \mu \mathrm{M})$ against Hep-G2 cells. On the other hand, CdSQ and LaSQ were the most effective against MDA-MB231, with $\mathrm{IC}_{50}$ values of 1.95 and $1.43 \mu \mathrm{M}$, respectively. 
3. The antibacterial and antifungal efficacies for the MSQ metal complexes decreased in the order AlSQ $>$ LaSQ $>$ CdSQ $>$ gentamycin $>$ NiSQ $>$ CoSQ $>$ Q $>$ S for antibacterial activity, and for antifungal activity followed the trend LaSQ $>$ AlSQ $>$ CdSQ $>$ ketoconazole $>$ NiSQ $>$ CoSQ $>$ Q $>$ S .

4. The results of conductivity confirm that the solutions were nonelectrolytes, except that of the $\mathrm{Al}$ metal complex, which was found to be ionic.

5. The average particle sizes for mixed ligand metal complexes with $\mathrm{Cd}$ (II) and $\mathrm{La}$ (III) were calculated to be 0.423 and $0.343 \mathrm{~nm}$, respectively.

6. On the basis of DFT calculations, we found the geometry of prepared metal complexes to be octahedral.

Supplementary Materials: The following are available online, Figure S1: ${ }^{13} \mathrm{C}$ NMR spectra of Salen ligand $(\mathrm{A})$ and $\mathrm{Cd}(\mathrm{B}$ and $\mathrm{D}), \mathrm{Al}(\mathrm{C}$ and $\mathrm{E})$ mixed 8-hydroxy quinoline complexes, Figures $\mathrm{S} 2$ : FT IR spectral of Salen Schiff base ligand (A) and its mixed 8-hydroxy quinoline (B) Co, (C) $\mathrm{Ni}$, (D) Cd, (E) Al, (F) La complexes in $4000-400 \mathrm{~cm}^{-1}$, Figures S3: The mass spectrum of Salen Schiff base ligand (A) and its mixed 8-hydroxy quinoline (B) CoSQ, (C) AISQ, (D) LaSQ complexes, Figures S4: PXRD powder pattern of Salen and its mixed CdSQ and LaSQ complexes. with 8-hydroxy quinolone, Figures S5: Characteristic DSC-TGA curve of Salen ligand (A) and and its mixed 8-hydroxy quin-oline (B) CoSQ, (C) NiSQ, (D) CdSQ, (E) AlSQ, (F) LaSQ complexes, Figure S6: Molecular electrostatic potential (MEP) surface of ligand, L (Keto-Enol) and complexes $\left[\mathrm{Co}(\mathrm{S})(\mathrm{Q})\left(\mathrm{H}_{2} \mathrm{O}\right)\right],\left[\mathrm{Ni}(\mathrm{S})(\mathrm{Q})\left(\mathrm{H}_{2} \mathrm{O}\right)\right],\left[\mathrm{Cd}(\mathrm{S})(\mathrm{Q})\left(\mathrm{H}_{2} \mathrm{O}\right)\right]$, and $[\mathrm{La}(\mathrm{S})(\mathrm{Q}) \mathrm{Cl}]$ using B3LYP/LANL2DZ, Figure S7: HOMO and LUMO charge density maps of ligand and complexes $\left[\mathrm{Co}(\mathrm{S})(\mathrm{Q})\left(\mathrm{H}_{2} \mathrm{O}\right)\right]$, $\left[\mathrm{Ni}(\mathrm{S})(\mathrm{Q})\left(\mathrm{H}_{2} \mathrm{O}\right)\right],\left[\mathrm{Cd}(\mathrm{S})(\mathrm{Q})\left(\mathrm{H}_{2} \mathrm{O}\right)\right],\left[\mathrm{Al}(\mathrm{S})(\mathrm{Q})\left(\mathrm{H}_{2} \mathrm{O}\right)\right]+$ and $[\mathrm{La}(\mathrm{S})(\mathrm{Q})(\mathrm{Cl})]$ using B3LYP/LANL2DZ, Figure S8: Graph showing values of \% viability of (A) Hep-G2 and (B)MDA-MB231 breast cell lines in different concentration for Salen and its $\mathrm{Co}(\mathrm{II}), \mathrm{Ni}(\mathrm{II}), \mathrm{Cd}(\mathrm{II}), \mathrm{Al}(\mathrm{III}), \mathrm{La}(\mathrm{III})$ mixed 8-hydroxy quinoline -Salen Complexes, Figure S9: IC $_{50}$ Values of Salen and its $\mathrm{Cd}(\mathrm{II}), \mathrm{Al}(\mathrm{III})$ and $\mathrm{La}(\mathrm{III})$ mixed 8-hydroxy quinoline complexes against HEK-293 cell lines compared to cisplatin. Table S1: Results of antibacterial bioassay of Salen ligand, metal salt and its mixed 8-hydroxy quinoline with $\mathrm{Co}, \mathrm{Ni}$, $\mathrm{Cd}, \mathrm{Al}$, La complexes against different strains of bacteria and fungi, Table S2: Results of antifungal bioassay of Salen ligand, metal salt and its mixed 8-hydroxy quinoline with $\mathrm{Co}, \mathrm{Ni}, \mathrm{Cd}, \mathrm{Al}, \mathrm{La}$ complexes against different strains of bacteria and fungi, Table S3: Important optimized bond lengths $(\AA)$ and bond angles $\left({ }^{\circ}\right)$ of $\left[\mathrm{Co}(\mathrm{S})(\mathrm{Q})\left(\mathrm{H}_{2} \mathrm{O}\right)\right]$, Table S4: Results of Important optimized bond lengths $(\AA)$ and bond angles $\left({ }^{\circ}\right)$ of $\left[\mathrm{Ni}(\mathrm{S})(\mathrm{Q})\left(\mathrm{H}_{2} \mathrm{O}\right)\right]$, Table S5: Results of Important optimized bond lengths $(\AA)$ and bond angles $\left(^{\circ}\right)$ of $\left[\mathrm{Cd}(\mathrm{S})(\mathrm{Q})\left(\mathrm{H}_{2} \mathrm{O}\right)\right]$, Table S6: Results of Important optimized bond lengths $(\AA)$ and bond angles $\left(^{\circ}\right)$ of $\left[\mathrm{Al}(\mathrm{S})(\mathrm{Q})\left(\mathrm{H}_{2} \mathrm{O}\right)\right]^{+}$, Table S7: Important optimized bond lengths $(\AA)$ and bond angles $\left(^{\circ}\right)$ of $[\mathrm{La}(\mathrm{S})(\mathrm{Q}) \mathrm{Cl}]$, Scheme S1: Thermo gravimetric degradation steps for the prepared Mixed salen/8-hydroxy quinoline complexes with $\mathrm{Ni}(\mathrm{II}), \mathrm{Cd}(\mathrm{II}), \mathrm{Al}(\mathrm{III}), \mathrm{La}(\mathrm{III})$ from ambient temperature to $800^{\circ} \mathrm{C}$ at heating rate of $10^{\circ} \mathrm{C} / \mathrm{min}$, Scheme S2: Mass fragmentation of CdSQ and AlSQ complexes.

Author Contributions: Conceptualization, L.H.A.R. and M.R.S.; methodology, E.M.A. and B.S.A.-F.; software, M.R.S.; validation, M.T.B. and E.M.A.; formal analysis, E.M.A., B.S.A.-F. and D.A.E.-E.; investigation, L.H.A.R. and A.A.M.; resources, B.S.A.-F. and M.T.B.; data curation, D.A.E.-E., M.T.B. and E.M.A.; writing—original draft preparation, D.A.E.-E. and E.M.A.; writing—review and editing, L.H.A.R.; visualization, A.A.M. and A.M.M.E.-S.; supervision, L.H.A.R.; project administration, A.A.M.; funding acquisition, B.S.A.-F. All authors have read and agreed to the published version of the manuscript.

Funding: This research was funded by Deanship of Scientific Research at King Khalid University, grant number GRP/261/42.

Institutional Review Board Statement: Not applicable.

Informed Consent Statement: Not applicable.

Data Availability Statement: The data presented in this study are available on request from the corresponding author.

Acknowledgments: The authors would like to thank Deanship of Scientific Research at King Khalid University, Abha, Saudi Arabia, for funding this work through project number GRP/261/42. 
Conflicts of Interest: The authors declare no conflict of interest.

Sample Availability: Samples of the compounds are available from the authors.

\section{References}

1. Okasha, R.M.; Al-Shaikh, N.E.; Aljohani, F.S.; Naqvi, A.; Ismail, E.H. Design of Novel Oligomeric Mixed Ligand Complexes: Preparation, Biological Applications and the First Example of Their Nanosized Scale. Int. J. Mol. Sci. 2019, 20, 743. [CrossRef]

2. Qiu, S.; Xue, M.; Zhu, G. Metal-organic framework membranes: From synthesis to separation application. Chem. Soc. Rev. 2014, 43, 6116-6140. [CrossRef] [PubMed]

3. Phuengphai, P.; Youngme, S.; Gamez, P.; Reedijk, J. Catalytic properties of a series of coordination networks: Cyanosilylation of aldehydes catalyzed by Zn (II)-4, 4'-bpy-carboxylato metal complexes. Dalton Trans. 2010, 39, 7936-7942. [CrossRef] [PubMed]

4. Bhunia, A.; Dey, S.; Moreno, J.M.; Diaz, U.; Concepcion, P.; Van Hecke, K.; Janiak, C.; Van Der Voort, P. A homochiral vanadiumsalen based cadmium bpdc MOF with permanent porosity as an asymmetric catalyst in solvent-free cyanosilylation. Chem. Commun. 2015, 52, 1401-1404. [CrossRef]

5. Heine, J.; Müller-Buschbaum, K. Engineering metal-based luminescence in coordination polymers and metal-organic frameworks. Chem. Soc. Rev. 2013, 42, 9232-9242. [CrossRef] [PubMed]

6. Cui, Y.; Yue, Y.; Qian, G.; Chen, B. Luminescent Functional Metal-Organic Frameworks. Chem. Rev. 2011, 112, 1126-1162. [CrossRef]

7. Hu, Z.; Deibert, B.J.; Li, J. Luminescent metal-organic frameworks for chemical sensing and explosive detection. Chem. Soc. Rev. 2014, 43, 5815-5840. [CrossRef] [PubMed]

8. Pan, J.; Liu, C.-P.; Jiang, F.-L.; Wu, M.-Y.; Chen, L.; Qian, J.-J.; Su, K.-Z.; Wan, X.-Y.; Hong, M.-C. Diverse architectures and luminescence properties of two novel copper (I) coordination polymers assembled from 2,6-bis [3-(pyrid-4-yl)-1,2,4-triazolyl] pyridine ligands. CrystEngComm 2015, 17, 1541-1548. [CrossRef]

9. Morris, W.; Volosskiy, B.; Demir, S.; Gándara, F.; McGrier, P.L.; Furukawa, H.; Cascio, D.; Stoddart, J.F.; Yaghi, O.M. Synthesis, structure, and metalation of two new highly porous zirconium metal-organic frameworks. Inorg. Chem. 2012, 51, 6443-6445. [CrossRef]

10. Burns, C.J.; Field, L.D.; Hambley, T.W.; Lin, T.; Ridley, D.D.; Turner, P.; Wilkinson, M.P. X-Ray crystal structural determination of copper (II)-nitrilotriacetic acid-bis (N-methylimidazol-2-yl) ketone ternary metal complex. ARKIVOC 2001, 7, 157-165. [CrossRef]

11. Clarke, R.M.; Storr, T. The chemistry and applications of multimetallic salen metal complexes. Dalton Trans. 2014, 43, 9380-9391. [CrossRef]

12. Atwood, D.A.; Harvey, M.J. Group 13 Compounds Incorporating Salen Ligands. Chem. Rev. 2000, 101, 37-52. [CrossRef] [PubMed]

13. Karmakar, M.; Chattopadhyay, S. A comprehensive overview of the orientation of tetradentate N2O2 donor Schiff base ligands in octahedral complexes of trivalent 3d metals. J. Mol. Struct. 2019, 1186, 155-186. [CrossRef]

14. Alvarado-Monzon, J.C.; López, J.A.; de Riquer, G.A.A.; Cristobal, C.; Flores-Alamo, M.; Ruiz-Azuara, L. Iridium (I) homobinuclear metal complexes containing salen-type ligands as bridge. Polyhedron 2019, 161, 243-250. [CrossRef]

15. Roy, S.; Dey, A.; Drew, M.G.; Ray, P.P.; Chattopadhyay, S. A tetranuclear nickel/lead metal complex with a salen type Schiff base: Synthesis, structure and exploration of photosensitive Schottky barrier diode behaviour. New J. Chem. 2019, 43, 5020-5031. [CrossRef]

16. Karuppasamy, P.; Thiruppathi, D.; Ganesan, M.; Rajendran, T.; Rajagopal, S.; Sivasubramanian, V.K. Iron (III)-salen ion catalyzed soxidation of 1-cysteine and s-alkyl-1-cysteines by H2O2: Spectral, kinetic and electrochemical study. Polyhedron 2019, 159, 135-145. [CrossRef]

17. Pessoa, J.C.; Correia, I. Salan vs. salen metal complexes in catalysis and medicinal applications: Virtues and pitfalls. Coord. Chem. Rev. 2019, 388, 227-247. [CrossRef]

18. Liang, Y.; Duan, R.-L.; Hu, C.-Y.; Li, L.-L.; Pang, X.; Zhang, W.-X.; Chen, X.-S. Salen-iron complexes: Synthesis, characterization and their reactivity with lactide. Chin. J. Polym. Sci. 2017, 36, 185-189. [CrossRef]

19. Maru, M.S.; Barroso, S.; Adão, P.; Alves, L.G.; Martins, A.M. New salan and salen vanadium metal complexes: Syntheses and application in sulfoxidation catalysis. J. Organomet. Chem. 2018, 870, 136-144. [CrossRef]

20. Clarke, R.M.; Herasymchuk, K.; Storr, T. Electronic structure elucidation in oxidized metal-salen metal complexes. Coord. Chem. Rev. 2017, 352, 67-82. [CrossRef]

21. Vilsinski, B.H.; Murtinho, D.M.; Serra, M.E.; Soares, E.F.; Cruz, P.F.; Braga, G.; Borges, O.; Muniz, E.C.; Rubira, A.F.; Caetano, W. Interactions between copper (II) dibrominated salen metal complex and copolymeric micelles of P-123 and F-127. Colloids Surf. A Physicochem. Eng. Asp. 2017, 532, 583-591. [CrossRef]

22. Umemura, M.; Kim, J.-H.; Aoyama, H.; Hoshino, Y.; Fukumura, H.; Nakakaji, R.; Sato, I.; Ohtake, M.; Akimoto, T.; Narikawa, M. The iron chelating agent, deferoxamine detoxifies Fe (Salen)-induced cytotoxicity. J. Pharmacol. Sci. 2017, 134, 203-210. [CrossRef] [PubMed]

23. Thomas, F. Ligand-centred oxidative chemistry in sterically hindered salen metal complexes: An interesting case with nickel. Dalton Trans. 2016, 45, 10866-10877. [CrossRef] [PubMed]

24. Morales, G.; Delgado, X.; Galeano, L.-A. Effect of the halogen ligand in [Mn(salen)X] metal complexes on the catalytic styrene epoxidation in $\mathrm{scCO}_{2}$. J. CO2 Util. 2015, 12, 82-85. [CrossRef] 
25. Short, B.R.; Vargas, M.A.; Thomas, J.C.; O'Hanlon, S.; Enright, M.C. In vitro activity of a novel compound, the metal ion chelating agent AQ+, against clinical isolates of Staphylococcus aureus. J. Antimicrob. Chemother. 2006, 57, 104-109. [CrossRef]

26. Vanparia, S.F.; Patel, T.S.; Sojitra, N.A.; Jagani, C.L.; Dixit, B.C.; Patel, P.S.; Dixit, R.B. Synthesis, characterization and antimicrobial study of novel 4-\{[(8-hydroxyquinolin-5-yl) methyl] amino\} benzenesulfonamide and its oxinates. Acta Chim. Slov. 2010, 57, 600-667.

27. Enquist, P.-A.; Gylfe, Å.; Hägglund, U.; Lindström, P.; Norberg-Scherman, H.; Sundin, C.; Elofsson, M. Derivatives of 8hydroxyquinoline-Antibacterial agents that target intra-and extracellular Gram-negative pathogens. Bioorg. Med. Chem. Lett. 2012, 22, 3550-3553. [CrossRef]

28. Tsumaki, T. Nebenvalenzringverbindungen. IV. Über einige innerkomplexe Kobaltsalze der Oxyaldimine. Bull. Chem. Soc. Jpn. 1938, 13, 252-260. [CrossRef]

29. Omar, M.; Abd El-Halim, H.F.; Khalil, E.A. Synthesis, characterization, and biological and anticancer studies of mixed ligand metal complexes with Schiff base and 2, 2'-bipyridine. Appl. Organomet. Chem. 2017, 31, e3724. [CrossRef]

30. Aly, S.A.; Elganzory, H.H.; Mahross, M.H.; Abdalla, E.M. Quantum chemical studies and effect of gamma irradiation on the spectral, thermal, X-ray diffraction and DNA interaction with Pd (II), Cu(I), and Cd (II) of hydrazone derivatives. Appl. Organomet. Chem. 2021, 35, e6153. [CrossRef]

31. Abu-Dief, A.M.; Abdel-Rahman, L.H.; Abdelhamid, A.A.; Marzouk, A.A.; Shehata, M.R.; Bakheet, M.A.; Almaghrabi, O.A.; Nafady, A. Synthesis and characterization of new $\mathrm{Cr}(\mathrm{III}), \mathrm{Fe}(\mathrm{III})$ and $\mathrm{Cu}(\mathrm{II})$ metal complexes incorporating multi-substituted aryl imidazole ligand: Structural, DFT, DNA binding, and biological implications. Spectrochim. Acta A Mol. Biomol. Spectrosc. 2020, 228, 117700. [CrossRef] [PubMed]

32. Chemical Computing Group Inc. Molecular Operating Environment (MOE); Chemical Computing Group Inc.: Montreal, QC, Canada, 2014.

33. Abdel-Rahman, L.H.; El-Khatib, R.M.; Nassr, L.A.; Abu-Dief, A.M.; Ismael, M.; Seleem, A.A. Metal based pharmacologically active agents: Synthesis, structural characterization, molecular modeling, CT-DNA binding studies and in vitro antimicrobial screening of iron (II) bromosalicylidene amino acid chelates. Spectrochim. Acta A Mol. Biomol. Spectrosc. 2014, 117, 366-378. [CrossRef] [PubMed]

34. Darensbourg, D.J.; Ortiz, C.G.; Billodeaux, D.R. Synthesis and structural characterization of iron (III) salen metal complexes possessing appended anionic oxygen donor ligands. Inorg. Chim. Acta 2004, 357, 2143-2149. [CrossRef]

35. Ansari, K.I.; Grant, J.D.; Woldemariam, G.A.; Kasiri, S.; Mandal, S.S. Iron (III)-salen metal complexes with less DNA cleavage activity exhibit more efficient apoptosis in MCF7 cells. Org. Biomol. Chem. 2009, 7, 926-932. [CrossRef] [PubMed]

36. Hare, C.R. Visible and Ultra Violet Spectroscopy; John Wiley and Sons: New York, NY, USA, 1968; pp. $112-155$.

37. Abdalla, E.M.; Abdel Rahman, L.H.; Abdelhamid, A.A.; Shehata, M.R.; Alothman, A.A.; Nafady, A. Synthesis, Characterization, Theoretical Studies, and Antimicrobial/Antitumor Potencies of Salen and Salen/Imidazole Metal complexes of Co (II), Ni (II), Cu (II), Cd (II), Al (III) and La (III). Appl. Organomet. Chem. 2020, 34, e5912. [CrossRef]

38. Kidrič, J.; Hadži, D.; Kocjan, D.; Rutar, V. 1H and13C NMR study of 8-hydroxyquinoline and some of its 5-substituted analogues. Magn. Reson. Chem. 1981, 15, 280-284. [CrossRef]

39. Baker, B.C.; Sawyer, D.T. Proton nuclear magnetic resonance studies of 8-quinolinol and several of its metal complexes. Anal. Chem. 1968, 40, 1945-1951. [CrossRef]

40. Mahmoud, W.H.; Deghadi, R.G.; Mohamed, G.G. Preparation, geometric structure, molecular docking thermal and spectroscopic characterization of novel Schiff base ligand and its metal chelates. J. Therm. Anal. Calorim. 2016, 127, 2149-2171. [CrossRef]

41. Mahmoud, W.H.; Deghadi, R.G.; Mohamed, G.G. Novel Schiff base ligand and its metal metal complexes with some transition elements. Synthesis, spectroscopic, thermal analysis, antimicrobial and in vitro anticancer activity. Appl. Organomet. Chem. 2016, 30, 221-230. [CrossRef]

42. Abdel-Rahman, L.H.; Abu-Dief, A.M.; Shehata, M.R.; Atlam, F.M.; Abdel-Mawgoud, A.A.H. Some new Ag (I), VO (II) and Pd (II) chelates incorporating tridentate imine ligand: Design, synthesis, structure elucidation, density functional theory calculations for DNA interaction, antimicrobial and anticancer activities and molecular docking studies. Appl. Organomet. Chem. 2019, 33 , e4699. [CrossRef]

43. Ibrahim, E.; Abdel-Rahman, L.H.; Abu-Dief, A.M.; Elshafaie, A.; Hamdan, S.K.; Ahmed, A. The electric and thermoelectric properties of $\mathrm{Cu}$ (II)-Schiff base nano-metal complexes. Phys. Scr. 2018, 93, 055801. [CrossRef]

44. Mishra, N.; Poonia, K.; Soni, S.K.; Kumar, D. Synthesis, characterization and antimicrobial activity of Schiff base Ce (III) metal complexes. Polyhedron 2016, 120, 60-68. [CrossRef]

45. Ribeiro, N.; Roy, S.; Butenko, N.; Cavaco, I.; Pinheiro, T.; Alho, I.; Marques, F.; Avecilla, F.; Pessoa, J.C.; Correia, I. New Cu (II) metal complexes with pyrazolyl derived Schiff base ligands: Synthesis and biological evaluation. J. Inorg. Biochem. 2017, 174, 63-75. [CrossRef] [PubMed]

46. Liu, Y.-T.; Lian, G.-D.; Yin, D.-W.; Su, B.-J. Synthesis, characterization and biological activity of ferrocene-based Schiff base ligands and their metal (II) complexes. Spectrochim. Acta Part A Mol. Biomol. Spectrosc. 2013, 100, 131-137. [CrossRef] [PubMed]

47. Marzilli, L.G. Bioinorganic Catalysis; Reedijk J \& Marcel Dekker: New York, NY, USA, 1993.

48. Anjaneyulu, Y.; Rao, R.P. Preparation, characterization and antimicrobial activity studies on some ternary metal complexes of $\mathrm{Cu}$ (II) with acetylacetone and various salicylic acids. Synth. React. Inorg. Met. Org. Chem. 1986, 16, 257-272. [CrossRef] 
49. Santos, A.F.; Brotto, D.F.; Favarin, L.R.; Cabeza, N.A.; Andrade, G.R.; Batistote, M.; Cavalheiro, A.A.; Neves, A.; Rodrigues, D.C.; Dos Anjos, A. Study of the antimicrobial activity of metal complexes and their ligands through bioassays applied to plant extracts. Rev. Bras. Farm. 2014, 24, 309-315. [CrossRef]

50. Bisceglie, F.; Bacci, C.; Vismarra, A.; Barilli, E.; Pioli, M.; Orsoni, N.; Pelosi, G. Antibacterial activity of metal complexes based on cinnamaldehyde thiosemicarbazone analogues. J. Inorg. Biochem. 2020, 203, 110888. [CrossRef] [PubMed]

51. Dharmaraj, N.; Viswanathamurthi, P.; Natarajan, K. Ruthenium (II) metal complexes containing bidentate Schiff bases and their antifungal activity. Trans. Met. Chem. 2001, 26, 105-109. [CrossRef]

52. Joseyphus, R.S.; Nair, M.S. Antibacterial and antifungal studies on some schiff base metal complexes of zinc (II). Mycobiology 2008, 36, 93-98. [CrossRef] [PubMed]

53. Abyar, S.; Khandar, A.A.; Salehi, R.; Hosseini-Yazdi, S.A.; Alizadeh, E.; Mahkam, M.; Jamalpoor, A.; White, J.M.; Shojaei, M.; Aizpurua-Olaizola, O. In vitro nephrotoxicity and anticancer potency of newly synthesized cadmium metal complexes. Sci. Rep. 2019, 9, 1-11. [CrossRef]

54. Zhou, X.; Koizumi, Y.; Zhang, M.; Natsui, M.; Koyota, S.; Yamada, M.; Kondo, Y.; Hamada, F.; Sugiyama, T. Cadmium-coordinated supramolecule suppresses tumor growth of T-cell leukemia in mice. Cancer Sci. 2015, 106, 635-641. [CrossRef] [PubMed]

55. Karmakar, T.; Kuang, Y.; Neamati, N.; Baruah, J.B. Cadmium metal complexes and cocrystals of indium metal complexes of benzothiazole derivatives and anticancer activities of the cadmium metal complexes. Polyhedron 2013, 54, 285-293. [CrossRef] 